\title{
Dybbøl - et dansk og tysk nationalt symbol
}

Af Inge Adriansen

\author{
"Dybbøl er en af milestenene \\ i den tysk-danske historie» \\ Gerd Stolz, tysk historiker, 1992 1
}

Dybbøl Banke, Dybbøl Mølle og Dybbøl Skanser er et af de få steder i grænselandet, der besøges i udstrakt grad af danske og tyske. For begge folk synes stedet at appellere til nationalfølelsen. Når man en sommerdag færdes på Dybbøl, vil man uvægerligt møde både danske og tyske grupperejsende, der bliver ført rundt $\mathrm{i}$ skanserne og får fortalt, hvorfor netop dette sted har sin særlige betydning i deres egen nations historie. Disse beretninger er naturligvis forskellige - alt efter om turistføreren er dansk eller tysk. Men fælles for begge nationer er en fremhævelse af, at »Dybbøl er langt mere end navnet på en bakkekam og en landsby vest for Sønderborg«, som en tysk turleder ynder at udtrykke det. Dybbøl blev allerede i krigen 1848-49 til et begreb, og efter krigen 1864 til et nationalt symbol. Dybbøl er et af de få symboler fra de slesvigske krige, som har overlevet tidens omskiftelser. Den fortsatte livskraft i dette symbol kan ses af to helt nye initiativer på henholdsvis dansk og tysk side:

Den 18. april 1992 åbnede et dansk historiecenter på Dybbøl Banke. Her kan de besøgende få oplysninger om landskabet og de historiske begivenheder, der er knyttet til det. Fortiden søges gjort levende og nærværende gennem kombination af billeder og lyd, og bygningens form og dekoration forsøger at fortælle med på historien.

En anden historisk institution, "Deutsches Museum Nordschleswig«, blev indviet i Sønderborg den 8. maj, kun tre uger senere. Museet er skabt af det tyske mindretal, og ved indvielsen udgav man i samarbejde med Bund Deutscher Nordsleswiger et skrift af historikeren Gerd Stolz: »Düppel-Dybbøl1848-1849-1864-heute«. Det er en historisk vandrefører beregnet for de mange tyskere, der vil bese det historiske område.

Disse danske og tyske initiativer viser, at der fortsat er stor interesse for Dybbøl og stedets historie. Men hvad har danske og tyske gennem tiden forbundet med begrebet Dybbøl? Hvilken fortolkning af historien møder man 
i de nyeste danske og tyske brochurer og bøger? Forbinder nutidens ungdom noget som helst med begrebet Dybbøl? Hvad er intentionerne bag danske investeringer på godt 50 mill. i det nye historiecenter med tilhørende vejanlæg, p-pladser og frilæggelse af terræn? Og sidst men ikke mindst - hvad giver symboler livskraft?

Denne artikel er et forsøg på at besvare i det mindste nogle af disse spørgsmål. Den må nødvendigvis tage udgangspunkt i de militære begivenheder på bakkekammen vest for Sønderborg. Militærhistorien spiller en helt central rolle i eftertidens fortolkninger af stedet og den betydning, det fortsat tillægges.

\section{Dybbøl som slagmark i $1848-49$}

I april 1848 blev Dybbøl sogn besat af tyske tropper. Efter det danske nederlag ved Slesvig 23. april trak de danske tropper sig tilbage til Nørrejylland, Fyn

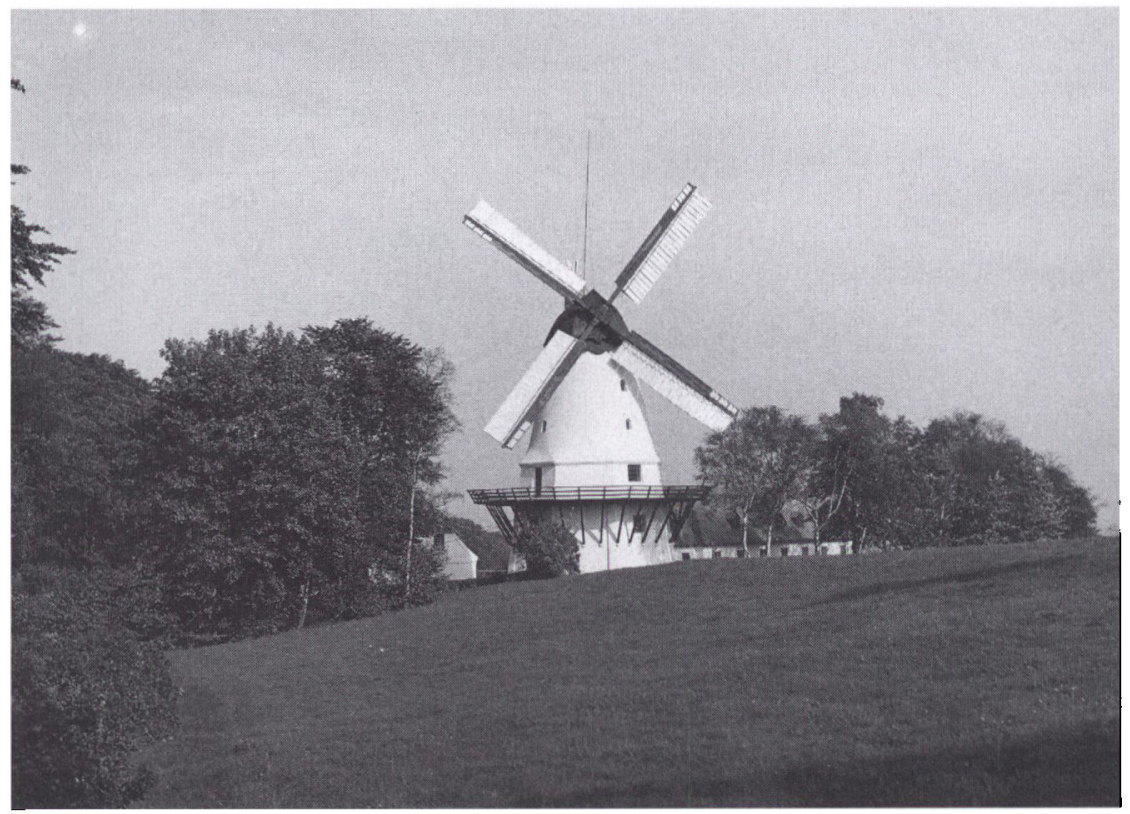

Dybbol Molle er et af danskhedens starkeste symboler. For mange danske fremstår mollen som et billede på den lille nations ukuelighed på trods af alle odds. I begge de slesvigske krige blev mollen skudt $i$ brand, men hver gang blev den genrejst. I tiden under tysk styre var mollerfamilien med til at fastholde mollen som et billede på danskhed. Endnu i 1980-erne kom der kontante beviser på Dybbol Molles fortsatte betydning for mange. En indsamling af midler til mollens restaurering gav et helt uventet hojt beløb $i$ lobet af få uger. "Der må ikke gå råd i nationalsymboler«, var begrundelsen hos mange af bidragyderne. Dybbol Molle er her fotograferet fra vest $i 1970$ af Niels Elswing. 
og Als. Derfor kunne Dybbøl-området indtages uden modstand. Der blev opsat tyske forposter på Dybbøl Bjerg og i Dybbøl by. De første kampe fandt derefter sted 28. maj, hvor den danske hær på Als forsøgte en fremrykning i Sundeved. Denne kamp var uden egentlig militær betydning, da de tyske troppers fremrykning i Jylland var blevet stoppet. Men den danske general Hedemann, der havde overkommandoen på Als, mente, at en heldig fægtning ville styrke kampånden, og han lod da foretage et angreb på de tyske forposter i Dybbøl. Efter en heftig kamp blev de fordrevet, men den tyske hovedstyrke i Nybøl kunne danskerne dog ikke anfægte. Befolkningen i Dybbøl fik nu dansk indkvartering $\mathrm{i}$ stedet for tysk. Et tysk modangreb satte ind en uge senere, 5. juni. Det var kongen af Hannovers fødselsdag, og de hannoveranske tropper ville gerne fejre dagen med en sejr. En tid tegnede situationen sig kritisk for den danske hær, men reserver fra Als nåede frem i rette tid, og de tyske tropper blev på ny trængt tilbage fra Dybbøl til Nybøl. Danske forposter blev opstillet på Dybbøl Banke og Dybbøl Bjerg, mens resten af sognet blev en slags ingenmandsland, hvor danske og tyske patruljer jævnligt strejfede rundt.

I en militær skildring af kampen omtales »de minderige dage, der først indskrev Dybbøls navn i Danmarks historie.$^{2}$ Kong Frederik 7. sendte 15. juni en hilsen til soldaterne, hvori han udtrykte sin tak med disse ord: »Det uforfærdede mod og den djærve udholdenhed, I alle har lagt for dagen $\mathrm{i}$ træfningerne, ved Sundeved og Dybbøl, har fornyet jeres krav på min beundring ...... ${ }^{3}$

Sidst på somren 1848 blev der sluttet våbenstilstand, og Sønderjylland blev styret af en fælles regering sammensat af danske og tyske. Det blev hurtigt de slesvig-holstenske synspunkter, der kom til at dominere, bl.a. blev embedsstanden udrenset for dansksindede. Den populære, dansksindede pastor Karstensen i Dybbøl blev udskiftet med den tysksindede pastor Axelsen i oktober 1848. På ejendommelig vis kom Dybbøl sogn herved til at afspejle hele Nordslesvigs situation: Der var danske forposter $\mathrm{i}$ den ene ende og tyske forposter $\mathrm{i}$ den anden ende af sognet. Præsten var slesvig-holstener, og befolkningen var dansksindet.

Den 3. april 1849 udløb våbenhvilen, og danskerne rykkede frem på Sundeved. Efter den ulykkelige tildragelse på Egernførde Fjord, hvor to danske linjeskibe blev sprængt i luften, blev Sundeved rømmet af danskerne, bortset fra brohovedet og forposterne på Dybbøl Bjerg. Tyske tropper rykkede nu ind, og 13. april indtog de også Dybbøl Bjerg. Under kampene var møllen snart $\mathrm{i}$ hænderne på den ene, snart på den anden part. Da aftenen kom, lå møllen i grus og aske. Møllens brand skyldtes, i følge danske kilder, at de danske batterier på Als havde skudt den i brand, i følge tyske kilder, at de 


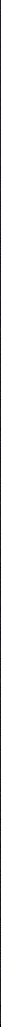

"Kampen på Dybbol Bjerg 5. juni 1848« er udfort af Jorgen Sonne, der var feltmaler under Treărskrigen. Han nåede ikke at komme til fronten for efter denne kamp. Det er teaterkrig $i$ dansk guldaldermaleri uden gru. Billedet er malet efter beretninger fra deltagere kort tid efter slaget, og det er i ovrigt najagtigt $i$ detaljerne. Garden spillede en central rolle i fordrivelsen af de tyske tropper fra Dybbøl, og sejren blev modtaget med begejstring af det danske folk. Stormagterne var derimod ikke begejstrede, da kampen blev betragtet som en dansk demonstration på et tidspunkt, hvor der foregik underforhandlinger. Foto Frederiksborgmuseet.

bayerske tropper havde sat ild til den. I samtiden var det en dåd, som begge parter gerne ville vedstå sig. Kampen den 13. april var den sidste væsentlige begivenhed, der foregik i Dybbøl i Treårskrigen. Befolkningen, der var flygtet under kampen, vendte tilbage, begyndte at rydde tomterne og tilså markerne.

\section{Den 5. juni som national mindedag}

I 1850 blev den fordrevne dansksindede præst $\mathrm{Kr}$. Karstensen genindsat i sit embede, og folk mødte atter talrigt op i kirken. Karstensen tog en række 
nationale initiativer, oprettede bl.a. en dansk bogsamling, udgav en dansk sangbog og arrangerede en bålfest på Dybbøl Bjerg 5. juni 1851 - på treårsdagen for den danske sejr. I festen deltog ikke blot beboere fra Dybbøl, men også mange fra Sønderborg og det øvrige Sundeved. Stemningen var præget af glæden over freden og tillid til fremtiden. I 1861 blev der igen afholdt en 5. juni fest i Dybbøl. Det var Karstensens efterfølger som sognepræst, F.R.C. Bülow, der nu tog initiativet. Festen indledtes med afsløringen af et stort mindesmærke for hans far, general Bülow, på Dybbøl Kirkegård. Ved festen besluttedes det, at man ville samles hvert tredie år for at festligholde 5. juni som en mindedag. Næste gang skulle således være i 1864, men af velbekendte årsager blev denne fest ikke til noget. Kun to gange, 1851 og 1861, blev der afholdt nationale fester til minde om 5. juni sejren på Dybbøl. ${ }^{4}$

Initiativet fra de to Dybbølpræster viser, hvorledes historiske myter kan opstå. Et uklogt dansk udfald fra Als mod Sundeved 28. maj 1848 efterfulgt af en kneben dansk fastholdelse af den i militær henseende betydningsløse forpost 5 . juni blev - i mangel af bedre sejre - til en regional festdag. Forestillinger af denne art havde man $i$ høj grad brug for både under krigen og $i$ mellemkrigsårene for at samle folket til styrkelse af kampvilje og bekræftelse af nationalt sindelag.

\section{Dybbøl Skanser anlægges 1861-63}

Under Treårskrigen havde bakkekammen Dybbøl Banke - Dybbøl Bjerg vist sig at være forholdsvis let at forsvare og velegnet til fægtninger, fordi man herfra kunne trække sig sikkert tilbage til Als. Det danske hovedforsvar blev efter 1860 anlagt ved Danevirke, men til supplement blev der ved Dybbøl og Fredericia anlagt flankebefæstninger. Herfra kunne man true en fjende i Jylland med udfald. Skansebyggeriet blev påbegyndt i 1861 efter at have været drøftet et par år. Anlægget af tre stærke forter ved Dybbøl var af Ingeniørkorpset beregnet til 1,6 mill rigsdaler, men i en sparetid med svære problemer både udenrigs- og indenrigspolitisk kunne dette beløb ikke bevilges. ${ }^{5}$ Dybbøl Skanser blev derfor skåret ned til ca. 800.000 rdl. Ved krigens udbrud i 1864 var der anvendt ca. 113.000 rdl., og det rakte kun til 10 små åbne værker. Det var langt fra de forestillinger om Dybbøl Skanser, som den danske befolkning havde på grundlag af forsvarsdebatten. Hverken befolkningen, hovedparten af hæren eller udenrigsministeren synes at have været klar over den katastrofale situation, da den danske regering i november 1863 vedtog en ny forfatning for kongeriget og Slesvig. Dette var et klart brud på de internationale aftaler, som Danmark havde indgået 
efter Treårskrigen. "Nu må det briste eller bære«, udtalte statsminister C.C.Hall. Ved Dybbøl kunne det kun briste.

\section{Dybbøl som slagmark i 1864}

Krigen begyndte 1. februar 1864. Størstedelen af den danske hær stod ved Danevirke, men efter få dages kamp besluttede den danske overkommando at rømme stillingen, da den var for let at omgå. Tilbagetrækningen fra Danevirke skete natten mellem 5. og 6. februar. I storm, sne og islag trak hæren sig tilbage. Da soldaterne ankom til Dybbøl i løbet af 7. februar, opdagede de til deres forbløffelse og dybe skuffelse, at forsvarsanlægget her endnu var helt ufærdigt. En dragon fortæller således om sit første indtryk. "Jeg skal ikke nægte, at da jeg havde beset de værker, jeg passerede forbi, blev jeg i høj grad skuffet - så skuffet, at jeg begyndte at tænke, at det måtte være forværker, og at de egentlige hovedværker vist måtte ligge længere tilbage«. ${ }^{6}$

De tyske tropper kunne have indtaget Dybbølstillingen straks, hvis den tyske efterretningstjeneste havde fungeret tilfredsstillende. Herved ville mange tyske og endnu flere danske militare og civile liv være sparet. Men de tyske generaler troede på Dybbølbefæstningens styrke. Den tyske presse sammenlignede Dybbøl med Sevastopol på Krim, og derfor indstillede de sig på en langvarig belejring som i Krim-krigen i 1856.

Ideen med flankebefæstningen var som næunt at true en fjende i Jylland med stadige udfald, men de danske tropper var så styrkemæssigt underlegne, at de ikke kunne foretage udfald. Hertil kom, at de tyske tropper straks placerede store styrker til en langvarig belejring af Dybbøl og Fredericia. Da en stor del af den danske hær var indesluttet $\mathrm{i}$ de to flankebefæstninger, blev Jylland besat - helt op til Limfjorden.

Der opstod nu den ejendommelige situation, at der blev kæmpet $\mathrm{i}$ over to måneder på Dybbøl - de sidste uger med konstante bombardementer, som også var til stor ulykke for civilbefolkningen - og i virkeligheden havde denne kamp ingen egentlig militær betydning. Den tjente mest til at retfærdiggøre den danske regering over for en befolkning, der stadigvæk følte sorg og skam efter rømningen af Danevirke.

På skrænten ved Gammelmark på Broagerland og i området vest for skansernes søndre fløj blev der opstillet ialt 102 preussiske kanoner, som kunne beskyde de første seks danske skanser. De daglange bombardementer herfra ødelagde efterhånden hele sydvestsiden af Dybbøl Banke. Dybbøl by lå lidt mere beskyttet, ca. $1,5 \mathrm{~km}$. mod nordvest, men også den ramtes hårdt. Før stormdagen var mere end hvert andet hus og gård bombeskadet eller beskudt. 


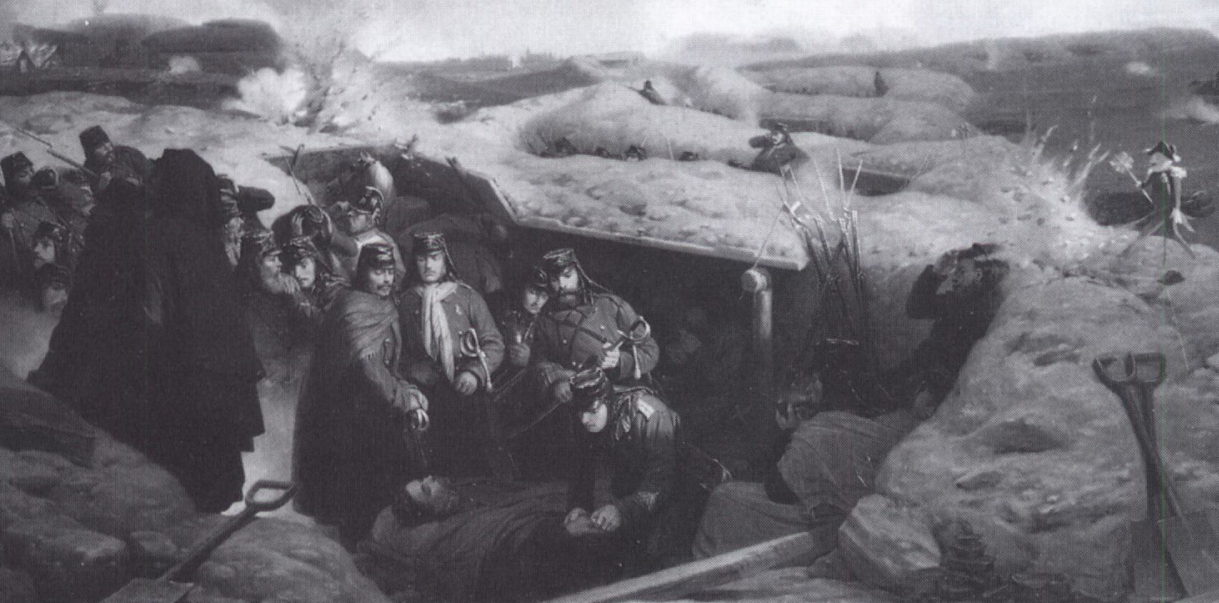

"I Dybbolstillingen « er malet af Jorgen Sonne på grundlag af hans egne oplevelser ved fronten $i$ 1864krigen. Der er en markant forskel til hans billede fra Treårskrigen. Her giver han en realistisk skildring af en af de forste skyttegravskrige $i$ krigshistorien. Billedet af de tratte soldater med kun nodtorftigt udstyr og $i$ ringe dakning for den konstante artilleriild barer prag af, at maleren ved selvsyn har oplevet den fortvivlende situation i Dybbol Skanser. Der gik 6 ar efter krigen, for Sonne var $i$ stand til at fuldfore maleriet. Med det afsluttes det danske bataljemaleri. Foto Frederiksborgmuseet.

Befolkningen var flygtet til Als eller længere ud på Sundeved. Her sad de nu i landbrugets såtid og lyttede til kanontordenen fra Dybbøl, velvidende, at hver kugle måske kunne betyde deres hjems udslettelse. Undertiden havde der ikke været tid til at medtage blot de mest nødvendige ejendele. ${ }^{7}$

Stormen trak ud, og i stedet blev der indledt et systematisk bombardement af Dybbøl og Sønderborg. I tiden 2.-17. april krævede de konstante bombardementer over 1.200 danske soldater og et ukendt antal civile ofre. De preussiske kanoners ild var forfærdelig. Næsten alle almindelige huse i Dybbøl brændte ned eller blev skudt i grus, Dybbøl Mølle således den 10. april. I de sidste 10 dage før stormen på skanserne faldt 5-6.000 skud pr. dag. Som forholdene udviklede sig, ville en tilbagetrækning til Als have været den rimeligste og mest 
forsvarlige løsning, da de danske krigsskibe kunne hindre en tysk overgang til Als. Men den danske overgeneral føjede den danske regering i ønsket om at forsege at holde stand, indtil den våbenhvile, man forhandlede om, kunne indtræde, og fredsforhandlinger påbegyndes.

Fastholdelsen af Dybbølstillingen skete således udfra politisk-taktiske synspunkter og havde kun lidt med militær-strategiske hensyn at gøre.

\section{Stormdagen 18. april}

Stormen indledtes med et meget hårdt bombardement fra $\mathrm{kl} .04 . \mathrm{Kl} \cdot 10$ om formiddagen ophørte beskydningen, og et lynangreb blev indledt af de preussiske stormtropper. Ialt 10.500 mand angreb de første 6 skanser, som erobredes i løbet af ca. $30 \mathrm{~min}$. Et dansk modangreb fra reserverne (8. Brigade) sinkede den endelige erobring $i$ en times tid. Men indsættelsen af yderligere 27.000 tyske stormtropper afgjorde kampen. Dybbøl Skanser faldt efter fire timers kamp. Fastholdelsen af stillingen denne sidste kampdag kostede danskerne ca. 1.700 døde, sårede og savnede samt henved 3.000 fanger foruden en afgørende ødelæggelse af Dybbølstillingen og Dybbøl Banke. Det tyske tab ved stormen var ca. 1.200 døde og sårede. Da mange soldater døde efter nogen tid på lazarettet, kan det præcise forhold mellem døde og sårede ikke opgives. ${ }^{8}$ Fredsforhandlinger blev indledt i London en uge senere. Trods ihærdig indsats fra neutrale stater blev der ikke opnået noget kompromis mellem de krigsførende parter. Da våbenhvilen udløb i juni, begyndte krigen derfor igen. De tyske tropper satte den 29. juni over Alssund fra Sandbjerg til Arnkil. Samme dag erobredes Als, og med dette andet store nederlag var krigen afgjort. Freden i oktober 1864 blev knusende for den danske helstat, som blev reduceret med $1 / 3$ af sit areal og $2 / 5$ af befolkningen.

Så vidt de nøgterne kendsgerninger. Det er denne kamp, som har givet anledning til, at Dybbøl er blevet til et begreb både for tyske og danske - og har været det siden 1864. Vi vil nu følge anvendelsen af Dybbøl som symbol på såvel dansk som tysk side. For begge parter var det af helt afgørende betydning, at der blev kæmpet 18. april. En belejring, som var endt med en dansk tilbagetrækning, ville for den tyske regering have været forsmædelig, selvom det ville have bragt Dybbølstillingen i tyske hænder, uden noget tysk blod blev udgydt. Den tyske krigskorrespondent Theodor Fontane beskriver dette forhold præcist: "Kun én frygt sneg sig ind i hjerterne, det ængstelige spørgsmål: Bliver danskerne stående, vil de holde ud? $\mathrm{Nu}$ ved vi, at denne frygt var velbegrundet, danskerne stod $i$ virkeligheden $i$ begreb med at rømme 
Dybbølstillingen. En eneste dags længere tøven og vore tapre batailloner ... havde højst sandsynligt mistet en storm- og sejrsdags velfortjente ære. Så ville alt have været omsonst, og jo større de forudgående anstrengelser des større vor modstanders latter og des ubarmhjertigere hans skadefryd. Denne fare svævede over Dybbøl den 17., og den blev følt som en fare. Men slagenes Gud havde bestemt det anderledes «.

For hovedparten af danskerne - måske soldaterne undtaget - var det også afgørende, at man blev i Dybbølstillingen og forsøgte at modstå angrebet. De ledende officerer var gået imod beslutningen om at fastholde stillingen, men regeringen havde indskærpet den kommanderende general Gerlach, at hæren skulle blive uden hensyn til omkostningerne. En af de danske officerer, løjtnant Hedemann, skriver efter slaget til sin kone om Gerlach: "Jeg ville ikke have været $i$ den mands sted for meget, thi han har disse og mange andre menneskers liv på sin samvittighed, fordi han ikke var stærk nok til at ville opgive en overgenerals stilling for at redde armeen. Det er min overbevisning, at var Du Plat og Rosens stemmer blevet hørt endnu den 16., istedenfor at Gerlach lystrede et ministerium.., så havde armeen været reddet, og dens are også .... ${ }^{10}$

Disse to samtidige bedømmelser er ret karakteristiske for vurderingen umiddelbart efter stormen på Dybbøl. Fra et militært synspunkt var det en forkert beslutning, at danskerne fastholdt stillingen til den bitre ende. Herom er vurderingen ens på dansk og tysk side. Det kan derfor ikke forbavse, at begge parter hurtigt fortrængte det irrationelle i stormen, og i stedet for skete der en heroisering og mytologisering af enkeltstående episoder i kampen.

\section{Dybbøl som Danmarks Thermopylæ}

Sammenligningen mellem kampen på Dybbøl i 1864 og spartanernes forsvar af bjergpasset ved Thermopylæ $i$ år 480 mod en overlegen persisk styrke blev fremført allerede i somren 1864. Jævnføringen med den tapre skare, der tappert - og forgæves - forsvarede sig mod en overlegen fjende, der invaderede hjemlandet, forekom helt indlysende i samtiden. Den første, der anvendte dette billedsprog, var P. Holst i en digtcyklus »Dybbølskandserne«, der blev udgivet til fordel for de faldnes efterladte. Her spørger digteren, om der i nutiden ikke findes spartanere, og han giver selv svaret:

Jo, det skal vidnes og sandes af alle:

Danmark har børn af spartanernes slægt.

Dybbøl, som værgedes mandigt og kjækt, tør vi Thermopylæ kalde. ${ }^{11}$ 


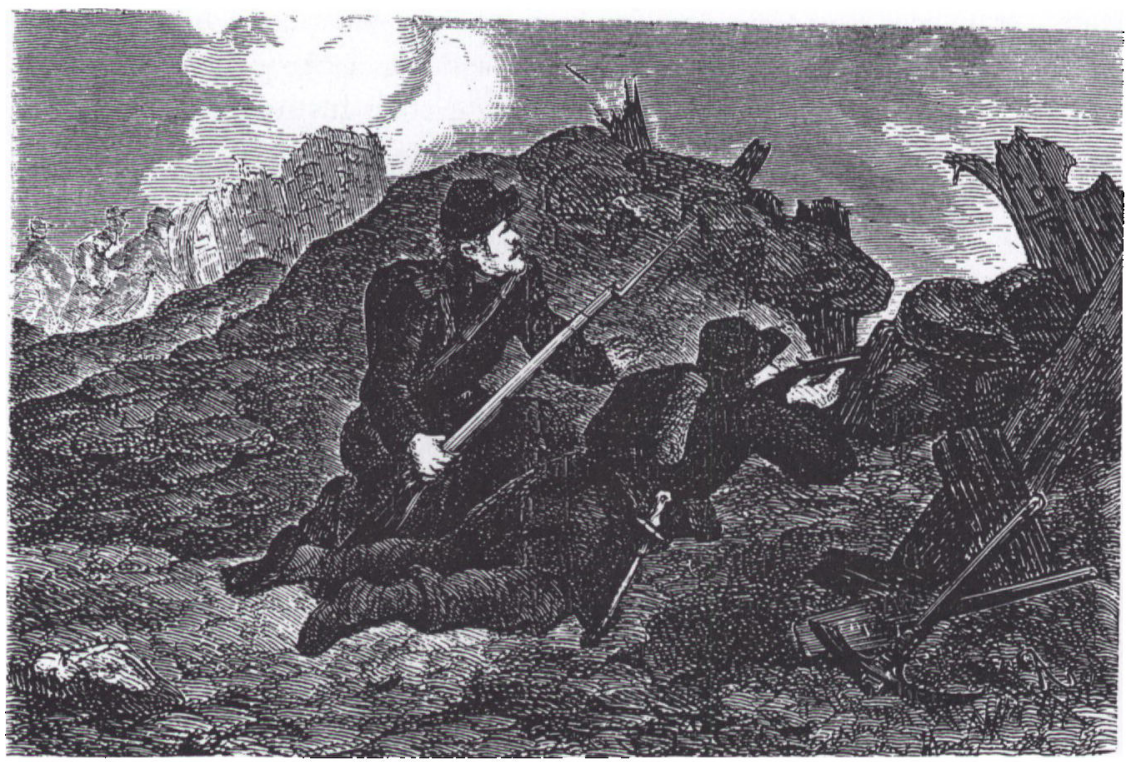

Det danske trasnit er et ojeblikshillede fra kampene $i$ Dybbol Skanser $i$ marts 1864. Det giver et trovardigt billede af de nasten sonderskudte skanser og de danske soldaters häblose kamp under den voldsomme beskydning. Trasnit af denne art var forlobere for en senere tids pressefotos og krigsreportager. Gengivet efter Illustreret Tidende 1864.

Efter Holst har mange danske anvendt dette heroiske billede på kampen. Kendtest er Drachmanns bog "Derovre fra Grænsen. Strejftog over det danske Thermopylæ (Als-Dybbøl) i april 1877 «, som udkom i et betydeligt oplag og blev genoptrykt til Genforeningen. Den har i høj grad været med til at befæste udtrykket, som også kan forekomme i nutidens turistbrochurer. Letfattelige billeder af denne art - af helt usammenlignelige begivenheder - er med til at sløre for forståelsen af, hvad der skete i 1864.

\section{Mytedannelser på dansk og tysk side}

Efter stormdagen blev Dybbøl hurtigt et symbol på uforfærdethed og tapperhed. Fra tysk side fremhævede man, at Slesvig var en tysk provins, der omsider var blevet løsrevet fra Danmark og nu for evige tider indlemmet i Tyskland. Breslauer Zeitung fastslog i en kommentar 20. april, at »det tyske folk aldrig vil glemme dagen ved Dybbøl.. thi det er for hele Tyskland, at sejren er vundet«. ${ }^{12}$

I danske dagblade var kommentarerne præget af sorg over det store tab og 


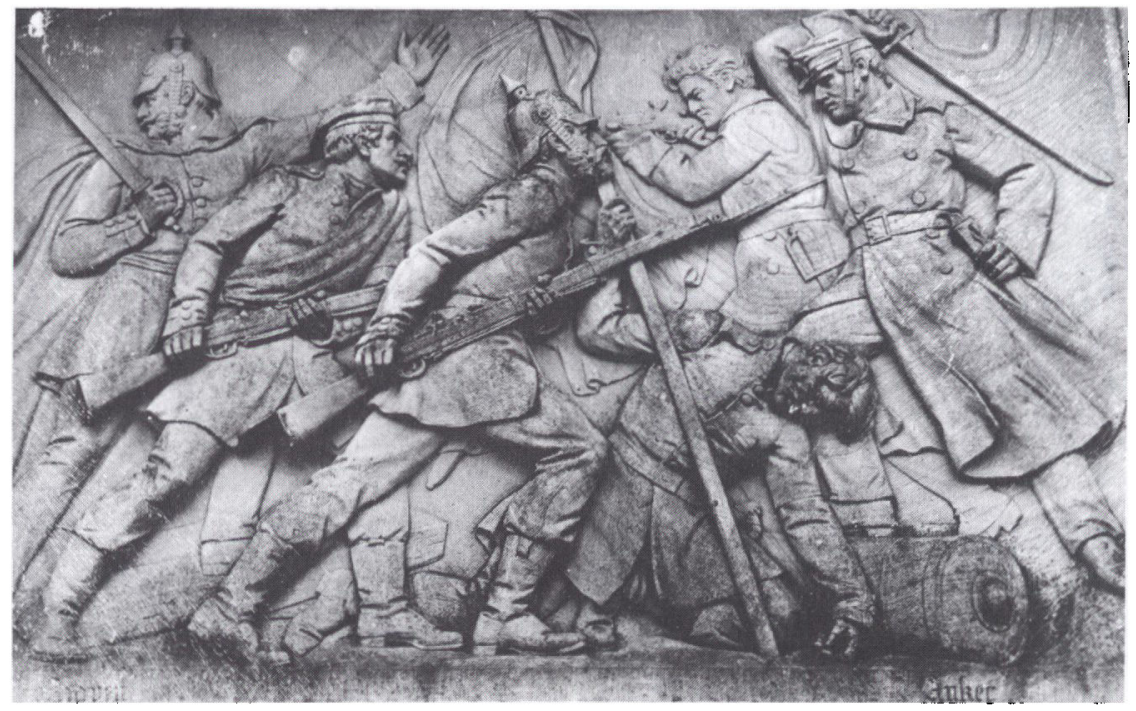

På det tyske sejrsmonument på Dybbol var der fire relieffer med scener fra kampene. Den realistiske stil, som fandtes $i$ de tyske trasnit fra kampene, hlev også anvendt $i$ de livfulde relieffer. På det ene fremstilledes den voldsomme kamp om skanse 2 den 18. april. Fire tyske soldater kamper her mod to danske. For fuldstandighedens skyld var der ihugget navne på de to hovedpersoner, general von Raven og lojtnant Ancker. Det er bemarkelsesvardigt, at den sejrende part viser, at man var styrkemassig overlegen. Ved et tilfalde blev dette relief bevaret som det eneste efter den danske odelaggelse af mindesmarket i maj 1945. Foto Museet på Sonderborg Slot.

bitterhed over den ulige kamp. Samtidigt fremhævede den national-liberale avis »Dagbladet «, at nederlaget ikke vakte samme mørke tanker som tilbagetoget fra Dannevirke. "Når hæren har gjort sin pligt, så vil nationen også gøre sin ved at vise fatning og $\bmod . . . \ll^{13}$

På begge sider var det nødvendigt at finde og fremhave begivenheder, der kunne tjene den fortolkning, som man gav det indtrufne. Derfor var der brug for beretninger om udvist heltemod, om helt usædvanlige præstationer fra officerer $o g$ menigt mandskab. Både fra dansk og fra tysk side fokuserede man på kampen om skanse 2, og i populære skrifter og skolebøger blev udvalgte personer fra denne kamp fremhævet.

Pioner Klinke blev på tysk side den mytologiske skikkelse, som symboliserede offervilje og fædrelandskærlighed. Skildringen af hans dåd indgik som en fast bestandel i mange tyske historie- og læsebøger frem til 1918. I korthed lyder den således: Den preussiske stormkolonne måtte standse ved palisaderne foran skanse 2. Her var ingen åbning at skue. Da trådte Klinke frem og sagde: "Jeg vil skaffe luft, hr. Løjtnant; hellere (ofre) én end to«. Derpå kastede han 
krudtsækken under palisaden og tændte lunten i den. Det skaffede hul - men Klinke omkom herved selv.

Denne begivenhed indeholder en sand kærne, idet en pionersoldat ved navn Klinke omkom under erobringen af skanse 2. Allerede før krigen var til ende, var der flere versioner af beretningen om "Klinke's Opfertod «. I 1866 gengav Th. Fontane således tre ret forskellige versioner af Klinkes indsats, og heraf fremgår, at det er højst tvivlsomt, om der var tale om en »offerdød«. Fontane slutter med at fastslå, at folket næppe ønsker at miste sin »Klinke«, dvs. forestillingen om heltedøden på ærens mark. ${ }^{14}$

Fontane var ikke blot en medrivende - og endnu læseværdig - krigskorrespondent. Han var også digter. Nogle år senere benyttede han sin digteriske frihed til at skrive "Der Tag von Düppel«. I en af stroferne skildrer han Klinkes heltemodige indsats - uden at stille de spørgsmålstegn ved handlingen, som han har gjort i sin samtidige krigsreportage. Tværtimod skildrer han handlingen som den frivillige offerdød, der sikrer vejen direkte til himlen. ${ }^{15}$

Det er i langt højere grad folket end militæret, som har dyrket myten om Klinke. I den preussiske generalstabs store værk »Der Deutsch-Dänische Krieg 1864 «, der udkom i 1887, omtales Klinke kun i en fodnote, hvor det fastslåes som en kendsgerning, at han blev forbrændt under sprængningen af skansen, men døde af en kugle. ${ }^{16}$ Selv i en regimentshistorie, udgivet af Brandenburgische Pionier-Bataillon Nr. 3, klares omtalen af Klinke på en enkelt side. I den saglige tekst beskrives, at han dør af en kugle, men et enkelt vers om den heltemodige soldat gengives for at antyde, at Klinke ofrer sig for fædrelandet. ${ }^{17}$

I "Vaterländisches Lesebuch Schleswig-Holsteinischer Kinderfreund" og "Deutscher Kinderfreund « finder vi derimod varianter af myten, ofte ledsaget af Fontanes digt Der Tag von Düppel eller en sang af E. Geibel Das Lied von Düppel. ${ }^{18}$ I kejsertidens Tyskland fik folket således sin Klinke i mange udgaver. Den sidste opblomstring af myten ses $\mathrm{i}$ en ungdomsbog "Der Schleswigholsteinische Befreiungskrieg«, som udkom i 50året for krigen. Her slutter skildringen af Klinkes død med en omtale af hans kone og tre børn, der levede under fattige kår. Til trods for disse forpligtelser valgte Klinke offerdøden: "Kærlighed til fædrelandet, begejstringen for soldateræren lod ham helt glemme sine egne interesser $\ll{ }^{19}$

I 1914 var der grobund for en holdning som denne, men ikke efter 1919. Dette må være grunden til, at Klinke synes næsten helt fraværende i Weimartidens skolebøger.

Det nærmeste danske modstykke er lojtnant Johan Ancker, skanse 2's tapre forsvarer. Ancker var militært uddannet, men havde svært ved at affinde sig med det rolige liv i den bornholmske milits. Han forlod derfor hæren og forsøgte at ernære sig som skuespiller på et københavnsk forlystelsestea- 
ter. Da krigen stod for døren i december 1863, meldte han sig til tjeneste igen. Ancker var med i tilbagetrækningen fra Danevirke og blev senere artillerikommandør i skanse 2, hvor han havde ansvaret på skift med løjtnant Castenschiold. Under belejringen udmærkede han sig ved såvel dristighed som et aldrig svigtende lune og blev meget populær hos sit mandskab. Castenschiold og Ancker var hinanden lig med hensyn til militær dygtighed, men ikke slagfærdighed, og kun Ancker blev berømmet i samtiden. Det skyldes især hans fanden-i-voldske facon og mundrappe talemåder, som sikrede ham mandskabets hengivenhed, fjendens beundring og kongens bevågenhed. Den 17. april hædredes han med ridderkorset og som en personlig gave fra kongen medfulgte en prægtig kappe. Ved tilfangetagelsen 18. april lagde man fra tysk side vægt på at få Ancker i levende live. I følge den samtidige tradition, gengivet af Th. Fontane, fik Ancker udleveret sin sabel igen af Prins Friedrich Carl med ordene: "En så ridderlig soldat må man ikke fratage sablen ${ }^{20}$

Efter hjemkomsten fra fangenskabet blev Ancker hyldet og fik overrakt en æressabel som en særlig hilsen fra 2.000 landsmænd. Han forlod imidlertid hurtigt militærtjenesten, da fredstidens stilfærdige og uglorværdige tjeneste ikke passede til hans temperament. Men hans ry var usvækket, og trods de få års ansættelse skænkede rigsrådet ham en betydelig, livslang pension. Med de mange fester, der holdtes til hans ære, fik han smag på at tilbringe sin tid på værtshuse. ${ }^{21}$ Helbredet blev ødelagt, og han døde i 1876. Anckers indsats blev i 1882 taget op til revision af militærhistorikeren Otto Vaupell. Her fremhævedes især den dygtige indsats af underofficererne i skanse 2, og forestillingen om hans enestående indsats led et knæk. ${ }^{22}$ Dette svakkede dog ikke Anckers én gang vundne ry blandt menigmand. Herom vidner den opmærksomhed, som hvert år den 18. april blev udvist hans enke, som levede frem til Første Verdenskrig. ${ }^{23}$

\section{Dybbøl som symbol for tyske og danske 1864-1914}

Efter krigen besluttede den preussiske regering sig til at rejse et sejrsmonument på Dybbøl. Grundstenen blev lagt allerede i 1865, og i 1872 kunne et stort sandstensmonument indvies i Skanse 4, lige ved Flensborg Landevej. Det var et højt spir af sandsten, flankeret af fire statuer af preussiske soldater. På foden var der indsat fire store relieffer, ligeledes udført i sandsten med scener fra kampene på Dybbøl 18. april. Monumentet var udført af billedhuggeren Strack. Det var udført i kejsertidens karakteristiske nygotik og gav den besøgende et klart signal om, at Dybbøl Banke nu var et tysk område. Ved 


\section{Slantofen Rutmmer 2, ved $\mathfrak{D} \mathfrak{y b b g l}$}

Ricutenait gitucter,

ber pjorbe Bjenben fanmegen Sfabe, at be tubfe Dfficerer mantte erfjectoe bam og bane foolf for rae fle (5)utter, fant buorlebes ban bolbt ub til bet 2joerfe og formaglebe Senuunerne.

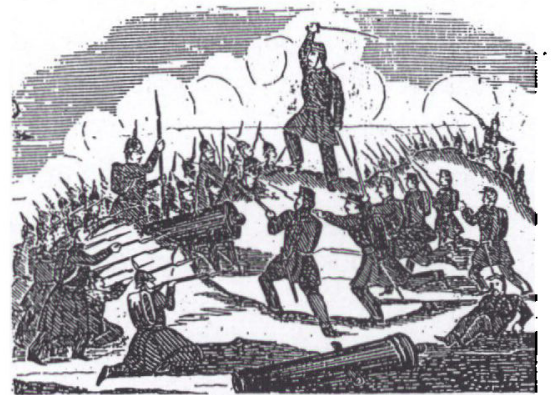

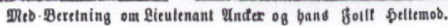
Jjobenfiaun.

3ut. Stranobergo fotlag.

gaaes + gog. og Comnieflonabanoelen, 5olmenogabe 18 Iroll bos Exalt gunb.

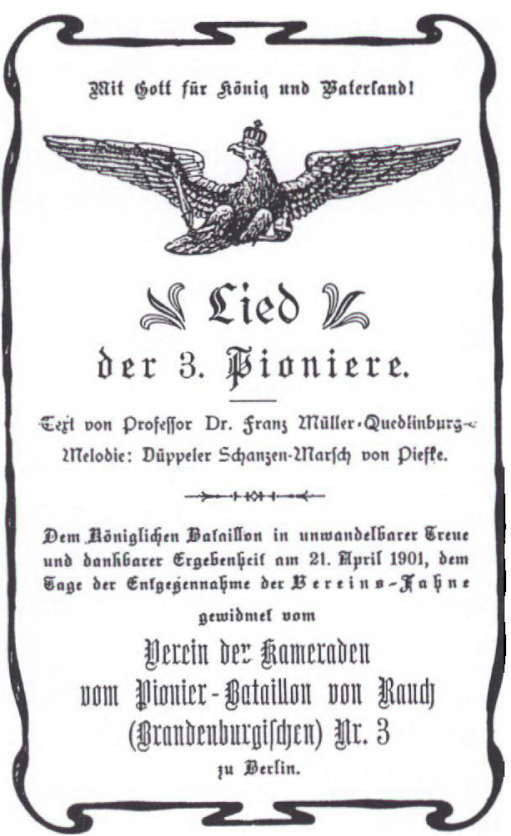

Skillingsviser blev flittigt anvendt både på dansk og på tysk side.Ikke blot i krigsâret men flere årtier senere kunne de gamle lejlighedssange genudgives og anvendes ved festlige sammenkomster blandt veteranerne fra 1864-krigen. Til venstre ses en vise fra samtidens storste danske visefabrikant, Julius Strandherg. Til hajre en tysk regimentsvise skrevet på melodien til Dybbol Skanse-march. Det var den musik, der blev spillet under stormen den 18. april. Foto Museet på Sonderborg Slot.

indvielsen skrev præsten i Ulkebøl et hyldestdigt til monumentet, der begyndte således:

\author{
Strahle weit auf Land und Meere \\ Siegesmal des Heldentums. \\ künde laut, auf dieser Erde, \\ Deutsches Reich, stiegst du empor. ${ }^{24}$
}

Et tilsvarende lidt mindre monument blev samme år rejst på Arnkil, hvor overgangen over Alssund fandt sted 29 juni. Disse sejrsmonumenter gav klare signaler om tyskhed, også til danske besøgende. Forfatteren Erik Skram fandt, at "disse rigt udarbejdede gotiske sandstensfantasier virker hæslige i landskabet. Om de ville passe på en åben plads mellem bygninger af mere eller mindre gammeltysk oprindelse ..., ved jeg ikke! men sikkert er det, at denne skøre højtstræbende sirlighed med spidser og rosetter midt $\mathrm{i}$ det bredt svulmende 
Düppel Denkmal blev rejst i $1871-72$ ved skanse 4 på det hojeste sted pó Dybbol Banke, hvor det rakte hojere op i landskabet end Dybbol Molle. Det var opfort $i$ sandsten og udformet i samtidens karakteristiske nygotik. Monumentet var mål for skole- og foreningsudfugter $i$ tiden frem sil 1920, og det var med til at understrege, at kamppladsen på Dybbol ogsd var et valfartssted for tyskere. Foto 1920 Det kongelige Bibliotek.

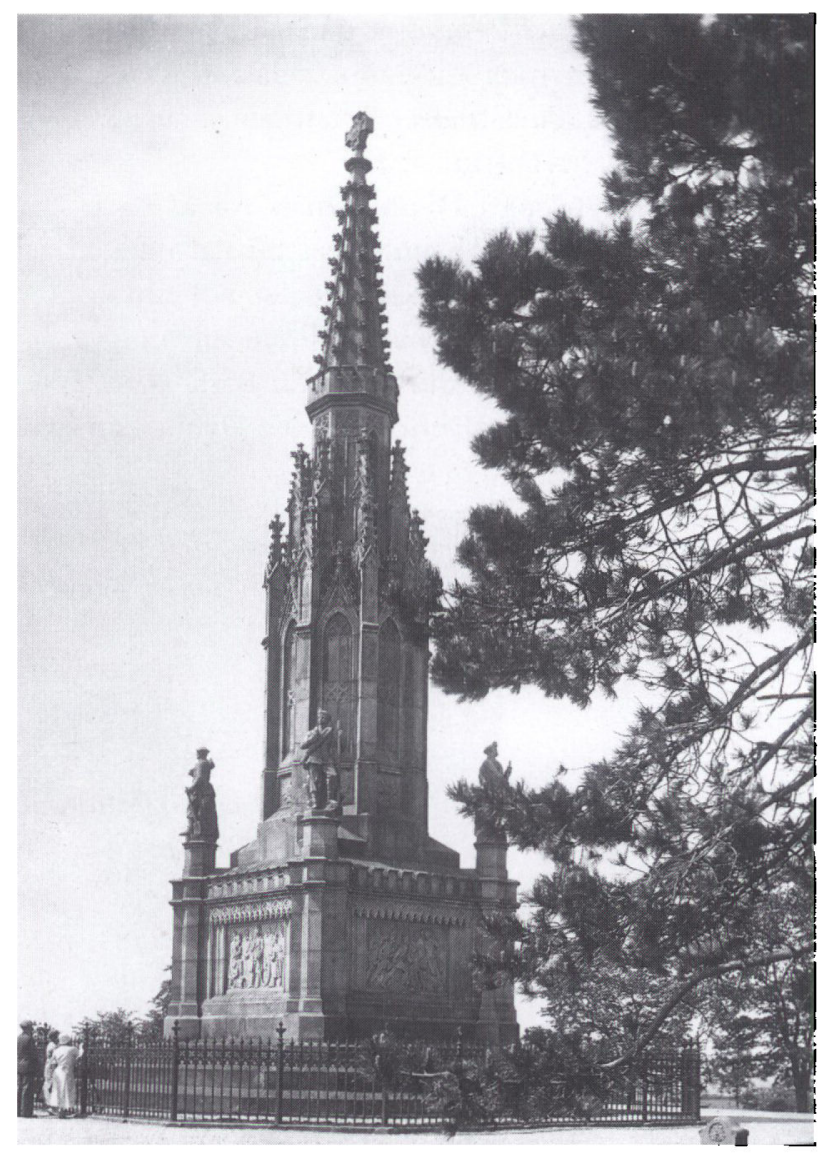

sletteland tager sig ud som sætstykker på en scene, som bragte man udstyret fra Tannhäuser ind i Elverhøj«. ${ }^{25}$

Denne negative vurdering deltes næppe af mange tilrejsende sydfra. DüppelDenkmal indgik for dem som en fast og meget væsentlig bestanddel af et besøg, ikke blot på Dybbøl men også i Sønderborg-området. Især var det et væsentligt indslag i skoleudflugter, hvor det tjente til opbyggelse af tysknational identitet hos ungdommen. I løbet af et par årtier blev det til et nationalmonument, der synes at have haft en tilsvarende styrke og udsagnskraft som Dybbøl Mølle for danskerne. Düppel-Denkmal blev prototypen på de mange tyske, nationale mindesmærker, som rejstes efter grundlæggelsen af Det tyske Kejserrige. Som mindesmarke var det en souvenir, der skulle erindre om noget bestemt. Som nationalt symbol skulle det anskueliggøre hele nationens fælles 
fortid og forventede fremtid. Udformningen i nygotik knyttede forbindelsen til tysk arkitektur-tradition og middelalderhistorie. Indholdet havde klar forbindelse til samtidens ideer om nationalstater. Det viste tyske soldater, der kæmpede mod rigets fjender.

Også efter 1864 blev Dybbøl anset for at have strategisk betydning. Det danske skanseanlæg blev ombygget hurtigt efter krigen. På dets ruiner blev anlagt »Festung Sonderburg-Düppel«. Befæstningen var stærkt armeret og bestod af to skanserækker på Sundeved-siden og én på Als. ${ }^{26}$ I løbet af 1870erne blev det imidlertid klart - også i Berlin - at Tyskland ikke behøvede at frygte et dansk angreb. Derfor mistede Dybbøl sin strategiske betydning. Det

Den ene af de fire hjornefigurer på det tyske monument på Dybbol forestillede en pionersoldat, og kunstneren synes at have tankt på pioner Klinke. $I$ folge en samtidig myte ofrede han sig frivilligt under stormen på skanse 2. Postkort med denne helteskikkelse var populare og udsendtes bl. a. i 1914 ved 50 års jubilaet for den $t y-$ ske sejr. Dyrkelsen of Klinke-myten ophorte efter kejserrigets sammenbrud. Efter den tyske genforening $i$ 1990 synes Klinke at have fået en lille renassance, idet der er udgivet en ny bog om ham og genopsat en mindeplade $i$ hans fodeby $i$ Brandenburg. Det forste billede, man moder på Deutsches Museum Nordschleswig, der blev indviet $i$ 1992, er også en fremstilling af Klinke. Foto Museet på Senderborg Slot.

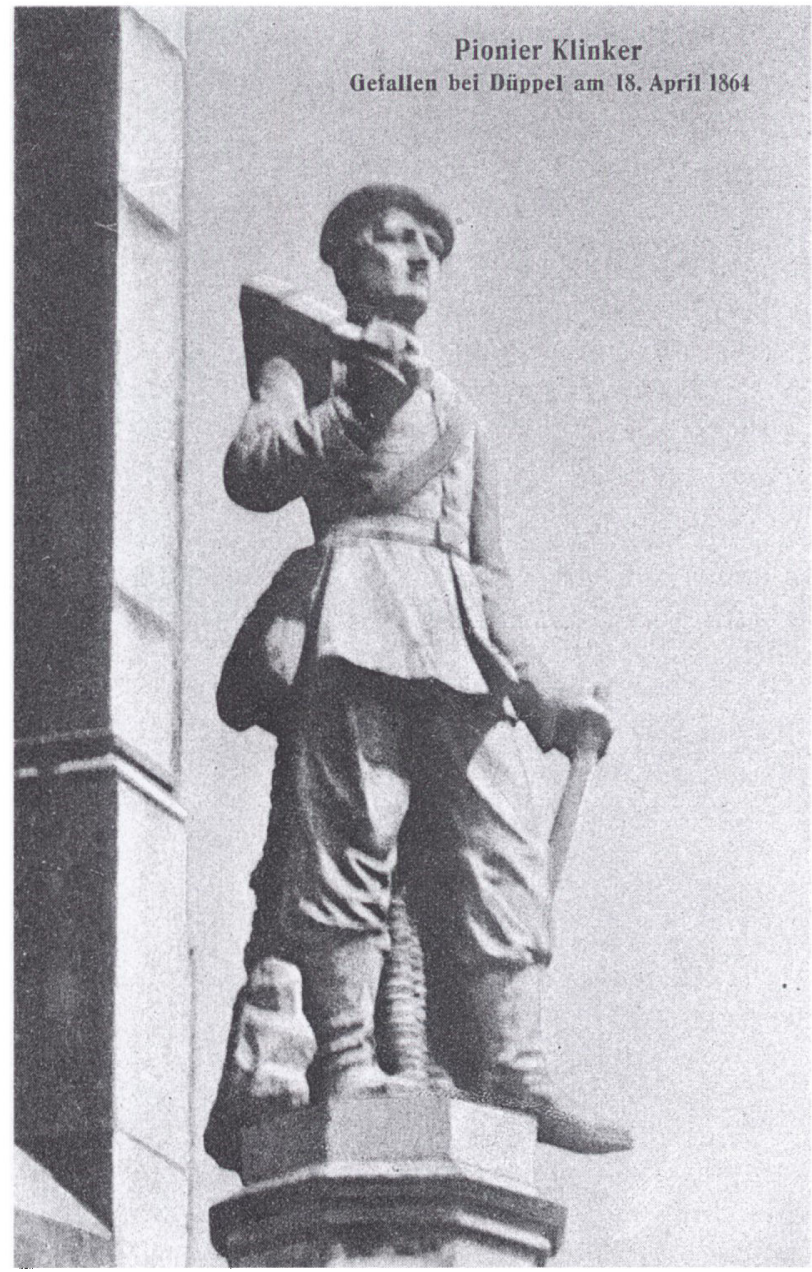


sidste mandskab blev i 1884 flyttet til Memel, og fæstningen blev desarmeret og nedlagt. Hermed var Dybbøl uden militær interesse. Kun skanseanlægget fra 1865 lå tilbage.

Men navnet Düppel var fortsat kendt, og kampene i 1864 hørte med til den historie, der blev indlært $i$ skolerne. Derfor var området gennem hele kejserperioden et meget søgt turistmål. De store fællesgrave på bakkekammen, hvor mange af de faldne på stormdagen er jordfæstet, var med til at understrege stedets betydning som slagmark, og allerede i $1865 \mathrm{blev}$ der her indrettet en smuk falles gravlund for tyske og danske.

Et nyt hotel "Düppelhöh « rejstes i umiddelbar nærhed af det tyske monument, midt mellem de danske skanser 4 og 5 og med udsigt over Vemmingbund. Her var plads til bespisning af 1000 gæster på én gang. Værten arrangerede omvisninger i skanserne og forhandlede whistoriske souvenirs«. Der var omkring to $\mathrm{km}$. at vandre fra centrum af Sønderborg til Dybbøl. Derfor indrettedes omtrent halvvejs en hyggelig café "Zum Pionier Klinke«. En statuette af krigeren prydede husets gavl.

Omkring i skanseanlægget fra 1865 rejstes mindesten over faldne preussere og østrigere. Det var næsten udelukkende officerer, der blev hyldet med disse sten. Én enkelt menig er dog også hyldet på denne vis - det er pioner Klinke, der har fået et helt lille anlæg ved skanse 2. Også over en dansk officer rejste tyskerne en mindesten. Det er - ikke overraskende - løjtnant Ancker, som blev hyldet af modstanderne.

De mange mindesten og hoteller og kroer var medvirkende til, at Dybbolområdets værdi som turistattraktion blev meget forbedret i slutningen af 1800årene. Fra nationalisme til turisme er vejen sjældent lang.

Også danske turister besøgte Dybbøl Banke. Ikke for at dvæle ved sejrsmonumentet men for at vandre i skanserne og besøge det mest fremtrædende danske mindesmærke - Dybbøl Mølle.

Møller Jørgen Hansen og hans hustru havde som de sidste civile forladt Dybbøl den 17. marts 1864. Efter krigen vendte de tilbage til Dybbøl Mølle, som de lod genopbygge. Møllen, der var "tvende gange skudt i grus, atter rejst som møllehus « blev nu et symbol på den ukuelige danskhed i Nordslesvig. De fleste rigsdanskere, der beså slagmarken og skanserne, afrundede rejsen med et besøg på Dybbøl Mølle. Medvirkende til at give møllen sin særlige position som dansk nationalt symbol var den allerede nævnte rejsebeskrivelse af Holger Drachmann: "Derovre fra Grænsen «, der udkom i 1878. Her skildrer han i stærke, negative vendinger det tyske sejrsmonument og fortsætter: "Når vi vende os fra fjendens monument, så har vi foran os de danskes monument - den gamle Dybbøl Mølle. Står den ikke der, lyslevende, sej og kraftig i sin 


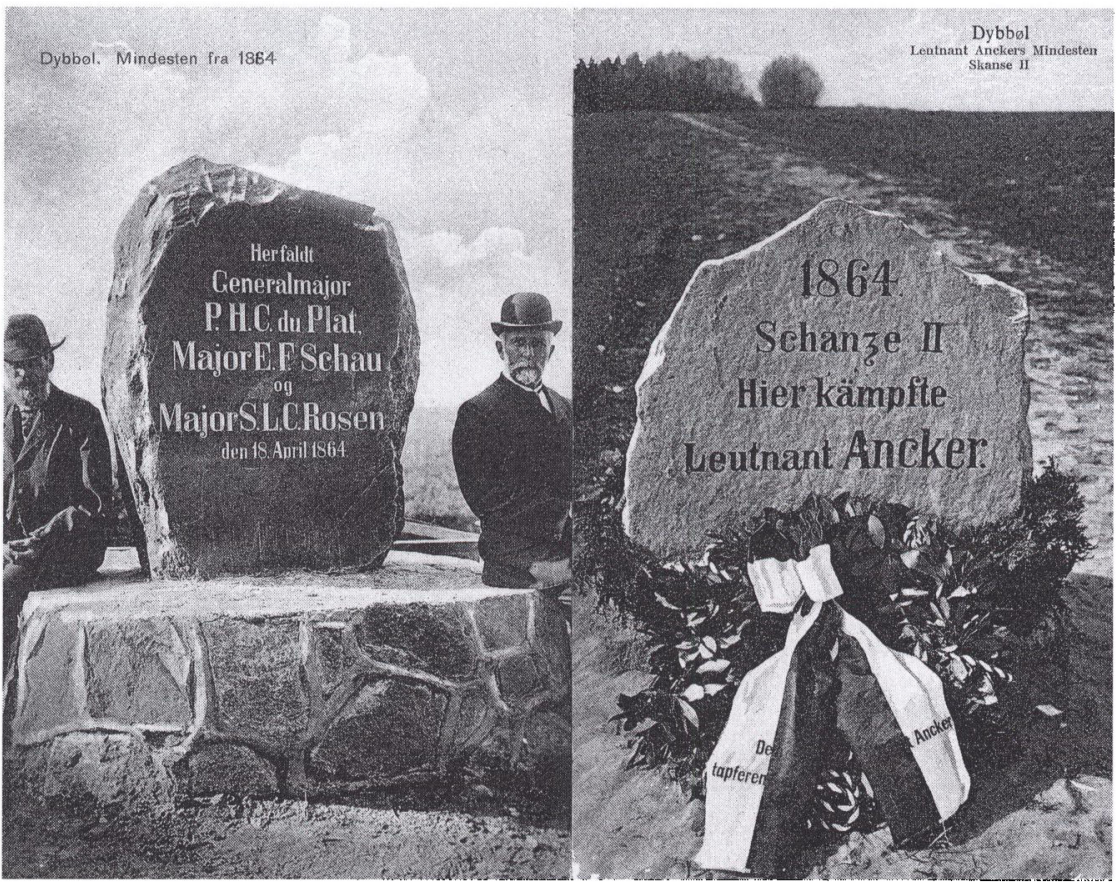

Mindesten over danske officerer rejst på Dybbol umiddelbart efter krigen. Til venstre ses en mindesten med dansk indskrift over tre af de ledende danske officerer. Denne sten var rejst for afståelsen af Sonderjylland i oktober 1864, og den fik lov at stå uantastet i tiden under tysk styre. Fotograf Carl C. Biehl, Gråsten. Til hojre er en tysk mindesten rejst over en dansk modstander. Det er den eneste tyske sten over en navngiven dansk offficer. Fotograf Jens Boisen Sonderborg. Begge postkort blev lavet i 1914 og genudgivet i 1920. Museet på Sonderborg Slot.

overbevisning om at stå på sin ret, tiltrods for at den står paa fjendens grund? Er der ikke kærne i den; og bider og tygger ikke dens stenhårde tænder al denne kærne, for at sigte skallerne fra og kun give kærne igen? Nedskudt og oprejst, brændt og opbygget, har den som en Fugl Fønix stedse rejst sig af sin aske, og hæver nu i dette øjeblik sine store, mørke vinger mod himlen, som om den ville tage aftenens skyer til vidne på, at den har båret meget og er rede til at bære mere. Og hvorfor? Den lever paa en idé; og når man lever paa en idé, kan man ikke falde sammen «. ${ }^{27}$

Drachmann sidestiller helt Düppel-Denkmal og Dybbøl Mølle som nationale monumenter og slår til lyd for, at møllen indgår i danske skolebøger $i$ lighed med Dybbøl-monumentet i tyske skolebøger. Han foreslår direkte skolekommissionen at gengive et træsnit af Dybbøl ledsaget af et vers, der hæver Dybbøl Mølle op i nationalsymbolikkens sfære og forjætter Genforeningen: 
Her står jeg, og vil ikke flytte min fod, som vagt på den vældige banke; Granater skal ikke rokke min rod, og ild ikke kvæle min tanke.

Min rod den munder i Danmarks bund.

Min tanke er den: der skal komme en stund, hvor hjerter omkring mig skal banke.

Omkap med det hjerte af egerod som molleren sætte i vingen lod;

Og slå med sin Vinge, og stå, hvor man stod, Med ære og ret; det er tingen! ${ }^{28}$

Efter Drachmann har en række andre danske forsøgt at skildre Dybbøl Mølle som symbol på danskheden. Men ingen har nået hans lyriske højder eller føjet noget til hans tolkninger. Fra 1877 var Dybbøl Mølle synonym med en ukuelig danskhed, der stod på rettens grund.

Dette billede af danskheden passede på mange måder til forholdene i Dybbøl sogn. Her holdt danskheden skansen i hele perioden under tysk styre. Hovedparten af lærerne og begge sognepræster, der virkede i perioden 1864-1920, var dansksindede. Ved det sidste tyske valg, rigsdagsvalget i 1912, blev der afgivet ca. $75 \%$ danske stemmer. Trods tysk overherredømme var Dybbøl sogn således såvel i overført betydning som i egentligste forstand en dansk bastion.

\section{Tyske sammenkomster og fester på Dybbøl 1890 og 1914}

Efter nedlæggelsen af »Festung Sonderburg-Düppel« i 1883 opstod muligheden for i højere grad at bruge Dybbøl-området som attraktion og som et væsentligt indslag i tyske fester. I september 1890 blev der afholdt en kejsermanøvre i Sundeved med centrum i Dybbøl-området. ${ }^{29}$ Det var en stor militærmanøvre med inddragelse af såvel flåden og hæren. Kejser Wilhelm II bivånede personligt hele manøvren, der strakte sig over 5 dage. Hovedopgaven de første dage var at kæmpe mod en nordfra kommende fjende. De sidste dage kom fjenden fra Als. Associationen til 1864 var indlysende, og manøvren var en magtfuld demonstration af, hvad tysk militær formåede. Der var trods afspærringer lagt stor vægt på at lade publikum følge de fingerede kamphandlinger. Værten på det store hotel Düppelhöh solgte således ståpladser á 50 Pf. og nummererede siddepladser til 2 og 3 Mark. Fra Düppelhöh var der udsigt over Vemmingbund og en betydelig del af skanserækken. På Broagerland tilbød gæstgiverne imidlertid gratis ståpladser for turister, der ville kigge over på Dybbøl, som i nogle 

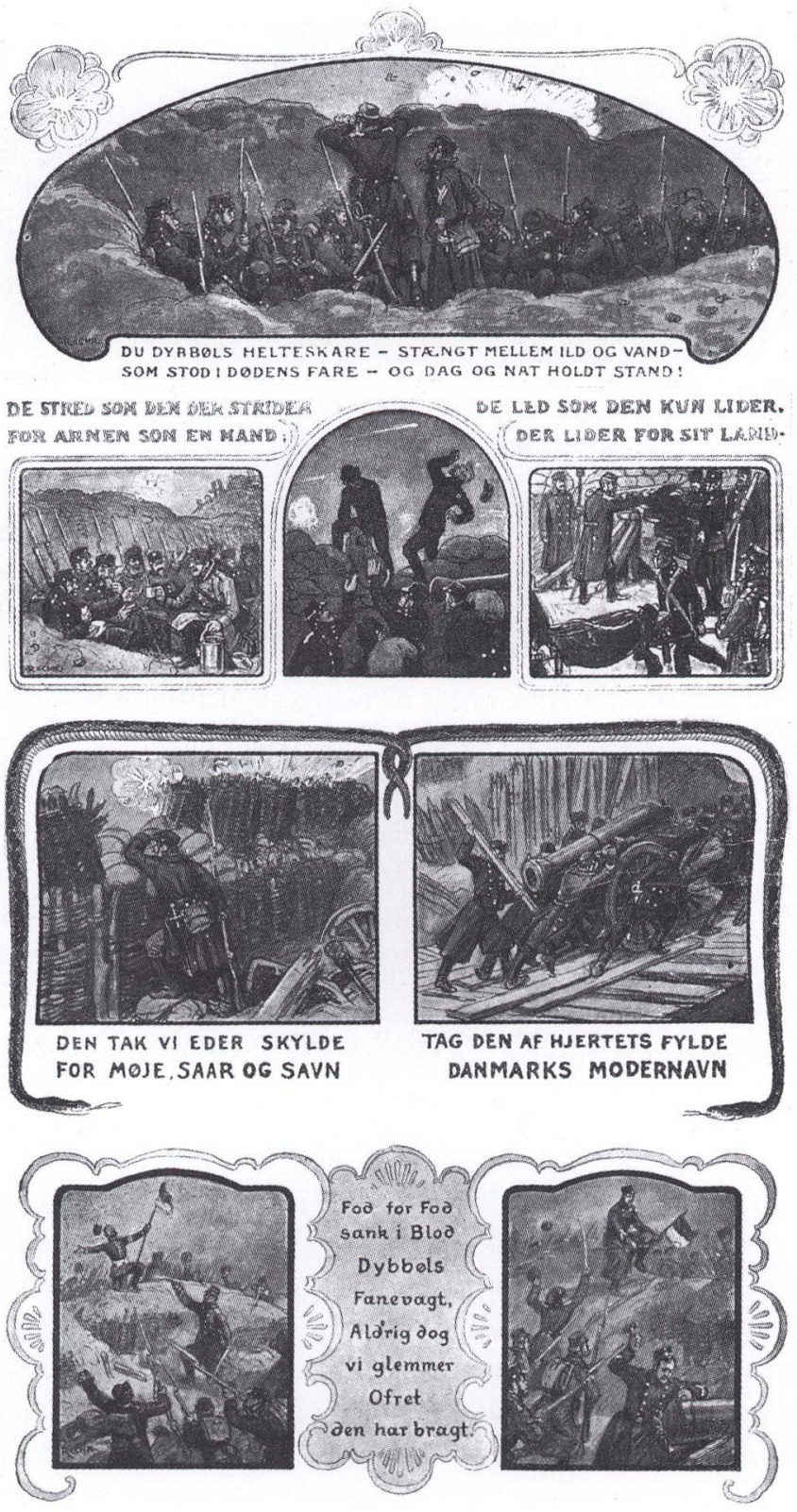

I 1904 udgav to officerer Axel Liljefalk og Otto Lütken varket "Vor sidste Kamp for Sonderjylland". Det var en omfattende skildring af krigen $i$ 1864, forfattet $i$ heroisk and og fremlagt i en folkelig stil med mange illustrationer. Hvert kapitel blev indledt med en vignet af Rasmus Christiansen og et par verslinjer fra sangene fra kampåret. Varket udkom i et stort oplag og blev genudgivet i 1914. Det har varet med til at fastholde forestillingen om de danske soldaters heltemodige kamp mod den store overmagt. Vignetter her er fra kapitlerne 34-37 i 1914-udgaven. 


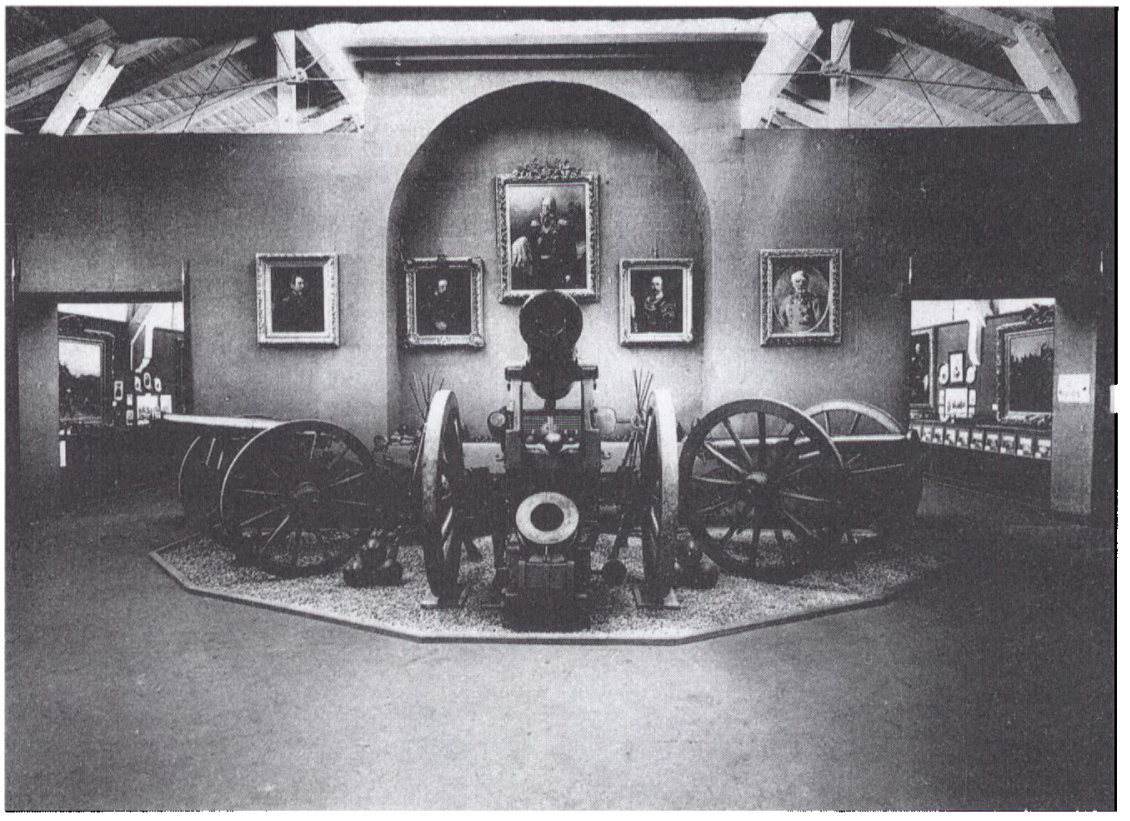

Düppel-Gedächtnis-Alusstellung, Sonderburg 1914. Mittelgruppe.

I 1914 fejredes 50 dret for den tyske sejr på Dybhol eller befrielsen af hertugdommerne, som det kaldtes. Sejren blev $i 1914$ fremstillet som begyndelsen til Tysklands samling og dermed en af grundstenene $i$ det tyske kejserrige. Ved jubilaet $i 1914$ blev der med assistance fra Tojhusmuseet i Berlin arrangeret en stor Düppel-Gedächtnis-Ausstellung i ridehuset foran Sonderborg Slot, der anvendtes som kaserne. Her vistes et vald af våben, malerier af officerer og kejserfamilie samt mange arkivalier. Vasentlige dele af udstillingen blev pd grund af krigsudbruddet i august 1914 ikke returneret til Berlin, og de indgik senere i 1864-samlingen pd Museet pd Sanderborg Slot. Genstandene anvendtes nu ikke langere til at belyse en lykkelig begivenhed i tysk historie, men til at skildre en af katastroferne i Danmarkshistorien. Foto Museet på Sonderborg Slot.

få dage atter var en militærattraktion af første klasse. Overalt i området kunne man købe en mindemønt med kejseren i kyrasséruniform på aversen og Düppel-Denkmal på reversen. Mønten var med til at understrege mindesmærkets og dermed også Dybbøls betydning som tysk nationalsymbol.

De to største tyske fester på Dybbøl blev afholdt den 18. april 1914 på 50 års dagen for stormen og den 29. juni 1914 på 50 års dagen for overgangen til Als og den endelige erobring af Slesvig. Den første fest tog især sigte på lokalbefolkningen. Den tyske avis, Sonderburger Zeitung opfordrede befolkningen $\mathrm{i}$ by $\mathrm{og}$ på land til at flagsmykke deres huse og deltage $\mathrm{i}$ festen » $\mathrm{i}$ 


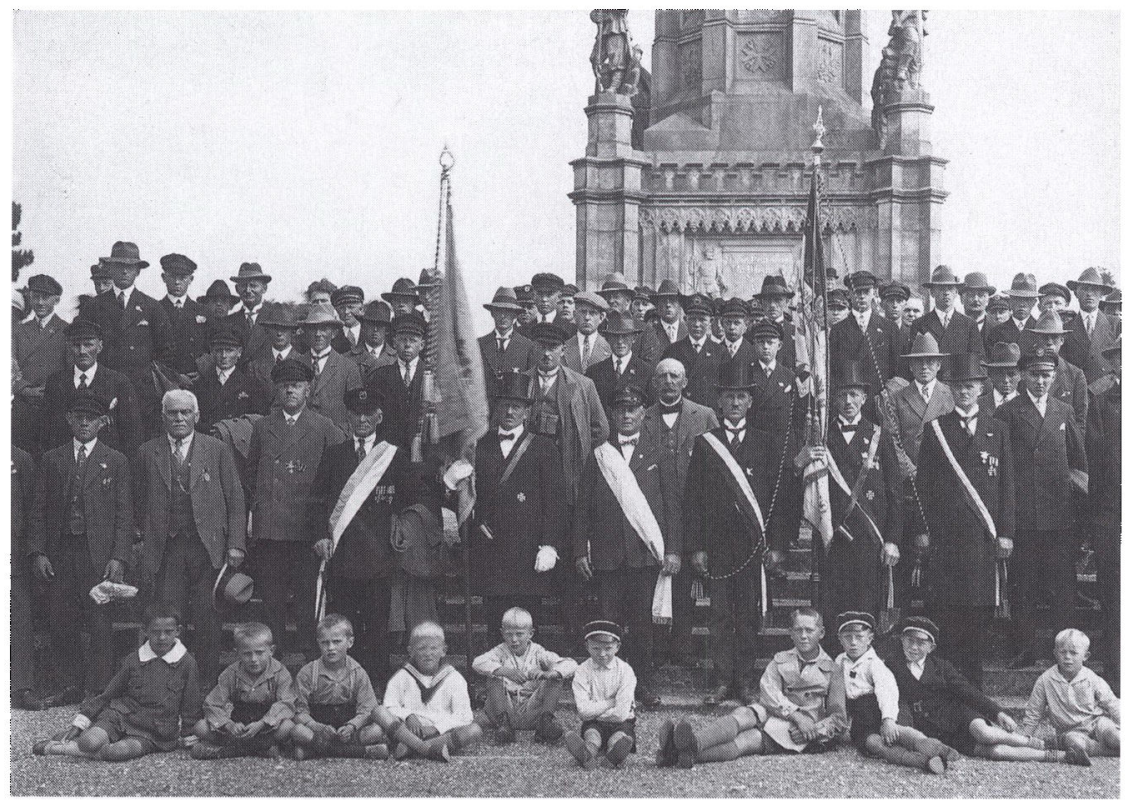

11914 blev der afholdt store fester på Dybbøl både den 18. april og den 29. juni, datoen for overgangen til Als og den endelige erobring af Sonderjylland. Soldaterforeninger, skoleelever og almindelige borgere $i$ Sonderborg deltog $i$ de store fester, som indledtes med optog med faner fra Sonderborg og kulminerede med taler af fremtradende personer og fallessang. Den 18. april var Düppel Denkmal centrum for festlighederne. Tilsyneladende var der ingen kvinder eller skolepiger med. Dybbøl var for tyskerne forst og fremmest et militart symbol og dermed en sag for mand. Foto Museet på Sønderborg Slot.

erindringen om den store betydning kampen på Dybbøl har haft for vor hjemstavns historie, og i mindet om de ofre, som krigsdeltagerne har bragt«. Alle skolebørn i Sønderborg og Dybbøl havde fri for at deltage i et festoptog, der gik fra Ringriderpladsen i centrum af Sønderborg til Düppel-Denkmal. Efter afsyngelsen af »Nun danket alle Gott« blev der holdt en række taler af fremtrædende skolefolk. Højtideligheden ved mindesmærket sluttede med afsyngelse af »Schleswig-Holstein meerumschlungen «. Herefter var der kransenedlæggelser ved de tyske fællesgrave, og mulighed for at høre militærkapellet fra Regiment Königin foran Hotel Düppelhöh.

Den tyske mindefest 18. april gav i øvrigt anledning til et sammenstød med dansksindede, som havde opsat en mindeplade på Dybbøl Mølle tidligt samme morgen. På pladen var indhugget:

Tvende gange skudt i grus

Atter rejst som møllehus 


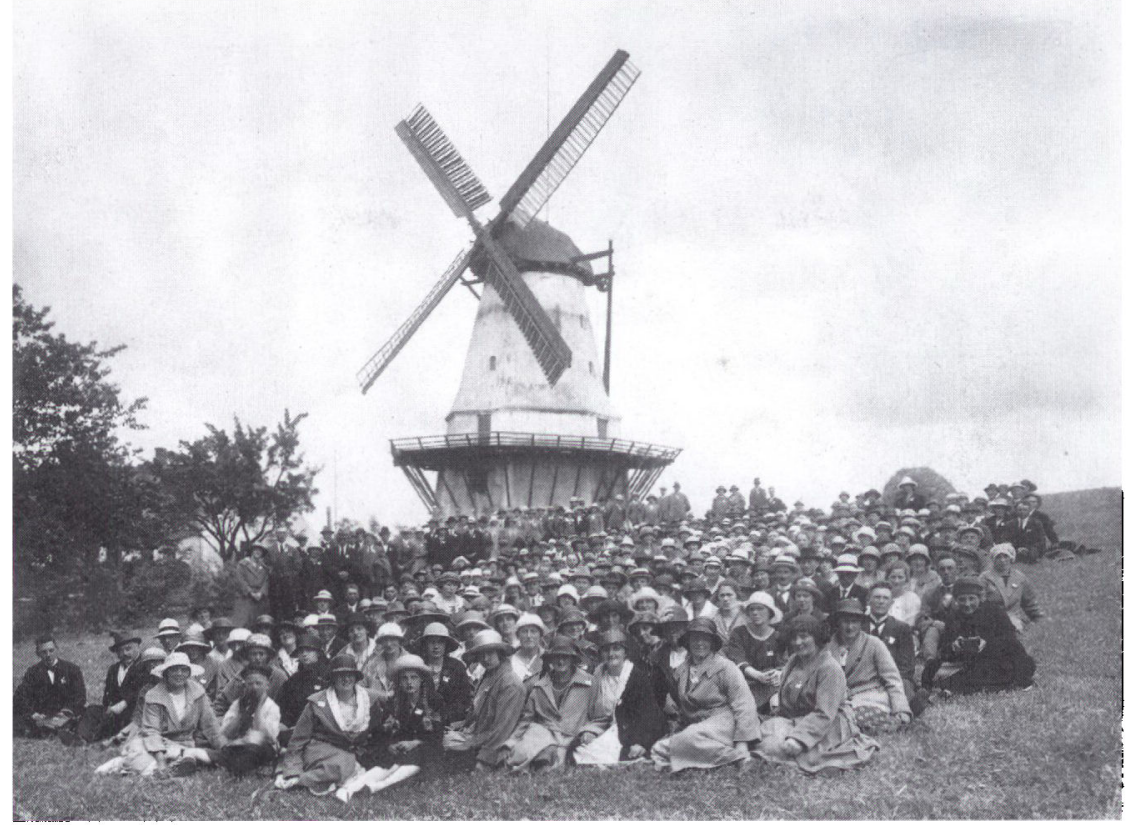

I 1930 fejredes 10 året for Genforeningen. Der rejstes genforeningssten over hele Danmark, og talrige danske foreninger $\log p a ̊$ udflugt $i$ det genvundne land. Et traditionelt indslag $i$ disse udflugter var at fà lavet et gruppebillede med Dybbal Molle i baggrunden. Ved sammenligning med tilsvarende tyske billeder er det iojefaldende, at kvinderne sjaldent er med $i$ opstillingerne omkring det tyske monument, men derimod i forgrunden ved Dybbol Molle. Mollen er ikke blot et symbol på den militare kamp. men måske $i$ endnu hojere grad et billede på den danske civile kamp. Foto Museet på Sonderborg Slot.

Vogter for et mindebo

Selv en bauta dansk og tro.

Spejd så langt dit øje når

Grav ved grav i marken står

Danske mænd gav livet hen

Troskab holder skansen end...

De to sidste linjer måtte uvægerligt opfattes som stærkt ophidsende af tysksindede. De kunne tolkes, som om kun de danske soldater udviste trofasthed, og dette måtte opfattes som meget sårende af de tyske veteraner, der deltog $\mathrm{i}$ festen. Derfor blev tavlen nedtaget og slået i stykker. Den beskadigede tavle blev opbevaret i møllehuset og genopsat i 1919.

Alt dette var kun en spag optakt til den store fest 29.-30. juni 1914. Da kom der ca. 2.000 veteraner rejsende fra hele Tyskland og Østrig. De var gratis gæster i Sønderborg i tre dage. Der var også deltagere fra den tyske regering, 


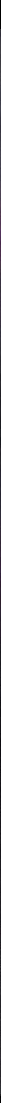

Et af indtryksfulde ojeblikke i forbindelse med Genforeningsfesten den 11. juli 1920 var hejsning af Dannebrog på den store flagmast, som de danske soldaterforeninger havde rejst på Dybbal Banke nar mollen. Der var givet tilladelse til, at der blev flaget med statsflaget. For forste gang siden 1864 blev Dannebrog hejst over Dybbol $i$ det ojeblik, kong Christian den 10. passerede forbi på vej til festen $i$ Dybbol Skanser. Dette er forklaringen på. at alle tilskuere står med ryggen til den hojtidelige flaghejsning. Fotoet blev anvendt til et af ärets mest populare postkort og indgik i billedmapper fra genforeningsàret. Det rummer tre nationale symboler: Dannebrog. Dybbol og kongehuset. Billedet er nasten en illustration til Axel Juels kantate fra 1920: "Vor langsels Landw. Den slutter: "Gud signe denne dag. da vi fik farlles håb og tro og konge, land og flag." Foto Museet på Sonderborg Slot.

hær og flåde. Da Kejser Wilhelm var forhindret $i$ at deltage, repræsenterede hans bror, Prins Heinrich, det tyske kejserhus. I den største af de tidligere tyske skanser blev der 29. juni afholdt en stor folkefest med taler bl. a. af generalfeltmarskal greve Haeseler, der havde deltaget som ung løjtnant i 1864krigen, og Prins Heinrich. Især prinsens tale til veteranerne vakte stor opmærksomhed. Han takkede for deres opofrelse og mod, lovede, at det vundne land 
ville blive fastholdt og tilføjede: "Jeg håber, at tysk ånd og tysk væsen vil gennemtrænge vores Nordmark lige til grænsen «. ${ }^{30}$

Denne tale blev det tyske kejserhus' sidste manifestation ikke blot på Dybbøl, men i hele Nordslesvig. Under festlighederne var der kommet et telegram til prinsen om straks at tage tilbage til Berlin. En udenrigspolitisk krise var under opsejling. Dagen før Dybbøl-festen, 28. juni, var den østrigske kronprins blevet skudt af en serber. Ekkoet af skuddet i Sarajevo gav således genlyd ved den sidste store tyske udfoldelse på Dybbøl.

Düppel-Gedächtnis-Feier fortsatte de næste to dage. Ved en middag i kurhuset holdt den tyske statsminister von Podbielski og den slesvig-holstenske overprasident von Bülow taler med et stærkt nationalt indhold, der knyttede begrebet Dybbøl nært sammen med tysk historie. Bülow omtalte Dybbøl som stedet for " den banebrydende tyske sejr i nutiden«, og han fremdrog en Dybbøl-morale: "Af Dybbølkæmperne har vi lært, at det ikke er modløshed, som fører til sejr, men alene den gamle preussiske tro på, at Preussens konger altid sejrer og alle vegne fastholder sejren. Dette være sagt til dem, der altid har hånden udstrakt efter vort land og intet har lært af Dybbøl«. ${ }^{31}$

\section{Genforeningsfesten i Dybbøl Skanser 1920}

Den 9. juli 1920 underskrev Christian 10. traktaten om de sønderjyske landsdeles indlemmelse i Danmark, og dette blev indledning til en uges festligholdelse af Genforeningen. ${ }^{32}$ Der indledtes med festgudstjeneste og stort folkemøde på Stadion i København. Næste dag red kongen over grænsen på den hvide hest og slettede herved symbolsk Kongeå-grænsen. Kulminationen nåedes trediedagen med en stor folkefest $i$ den største af skanserne på Dybbøl. Her mødtes kongehuset, regeringen og folketinget med henved 50.000 sønderjyder.

Hovedtalen blev holdt af lensgreve Schack, formand for Vælgerforeningen. Han indledte sin tale med at begrunde valget af festplads: "På Dybbøl Banke, det dyrebareste Danmark ejer, hvor fortid og nutid fører et sprog, der stærkere end mennesketunger formår det vidner om, at Herren har gjort store ting imod os, mødes Danmarks kongehus, regering og rigsdag, mødes Danmark selv med sønderjyske landsmænd « ${ }^{33}$ Schack mindedes Christian den 9.'s besøg i Dybbøl Skanser i februar og marts 1864. Genforeningen var en stor, næsten ufattelig glæde. "Hvem turde have håbet på dette, da den tyske Dybbølfest for 6 år siden skulle overtyde verden om, at dette land for Danmark var tabt for bestandigt? $\aleph^{34}$

Også i en række af de øvrige taler blev dette tema om Dybbøl som ramme om tyske og danske fester berørt. Genforeningsfesten kunne - efter flere taleres 


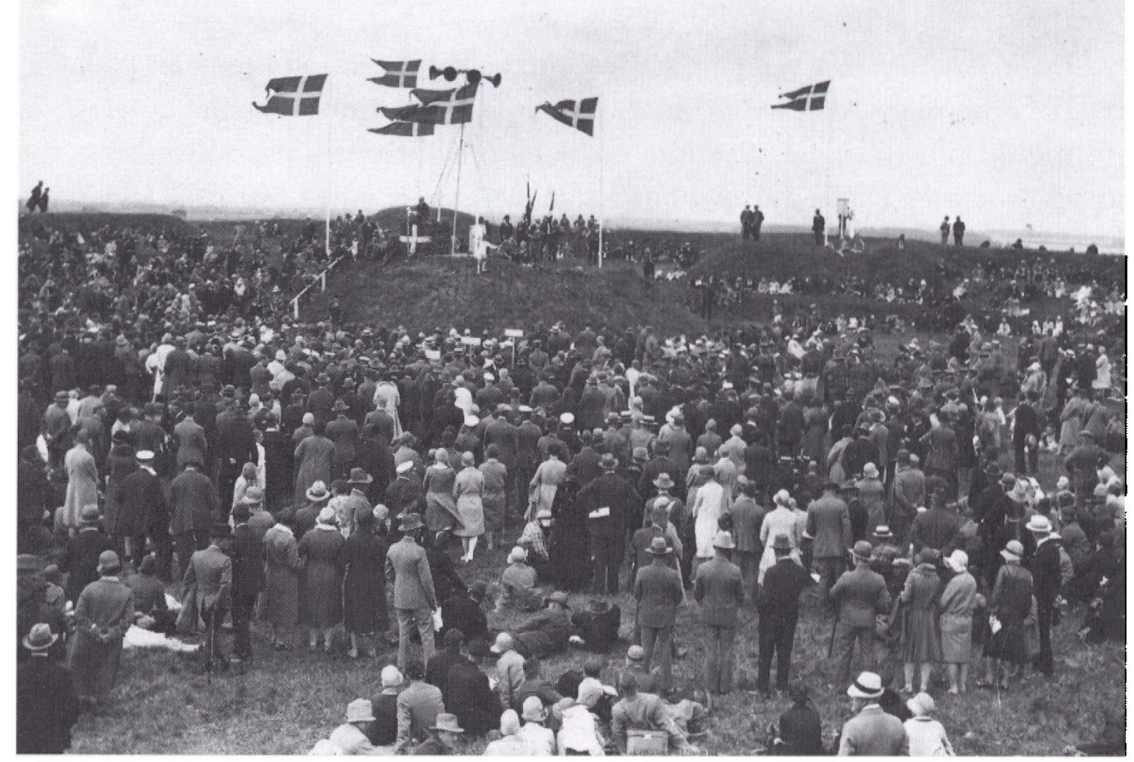

Den 15. juni er både Valdemarsdag og Genforeningsdag, dvs den dag, der indfortes dansk administration $i$ de sonderjyske landsdele. Dagen blev fejret med en stor fest i Dybbol skanser i 1930, hvor splitfluget var med til at understrege, at dette var en festdag både for det officielle Danmark og for det danske folk. Statsminister Stauning og andre fremtradende politikere holdt taler, og blandt tilhorerne var isar de generationer, der havde oplevet Genforeningen som voksne. Det var en fest af overvejende tilbageskuende karakter. Foto fra Berlingske Tidende 16. juni 1930.

mening - kun afholdes på det sted, hvor nederlaget havde udspillet sig. Fortidnutid-fremtid knyttedes herved sammen. Historiens morale blev uddraget således af Hans Lorenzen, der talte som repræsentant for Sonderjysk Arbejderforening: "Når vi på en højtidsdag som denne samles her på denne minderige Dybbøl banke, her hvor så meget blod flød, hvor den danske soldat kæmpede med heltemod mod en overmægtig fjende, - da mangler man ord til at udtrykke de følelser, der gennemtræenger hjertet. Da synes jeg, man mest rammende kan bruge de ord som hin konge dengang brugte: »Hvilken tilskikkelse ved Guds hjælp ${ }^{35}$

Hin konge var Preussens kong Wilhelm, som skrev således til sin hustru 2. september 1870 , da han havde modtaget kejser Napoleons kapitulation i Sedan. Trods alle ideer om forskelle på dansk og tysk national identitet møder vi her et markant fællestræk, som genfindes i næsten alle nationale bevægelser: Forestillingen om Guds hjælp. Denne tanke var - og er endnu for mange - 


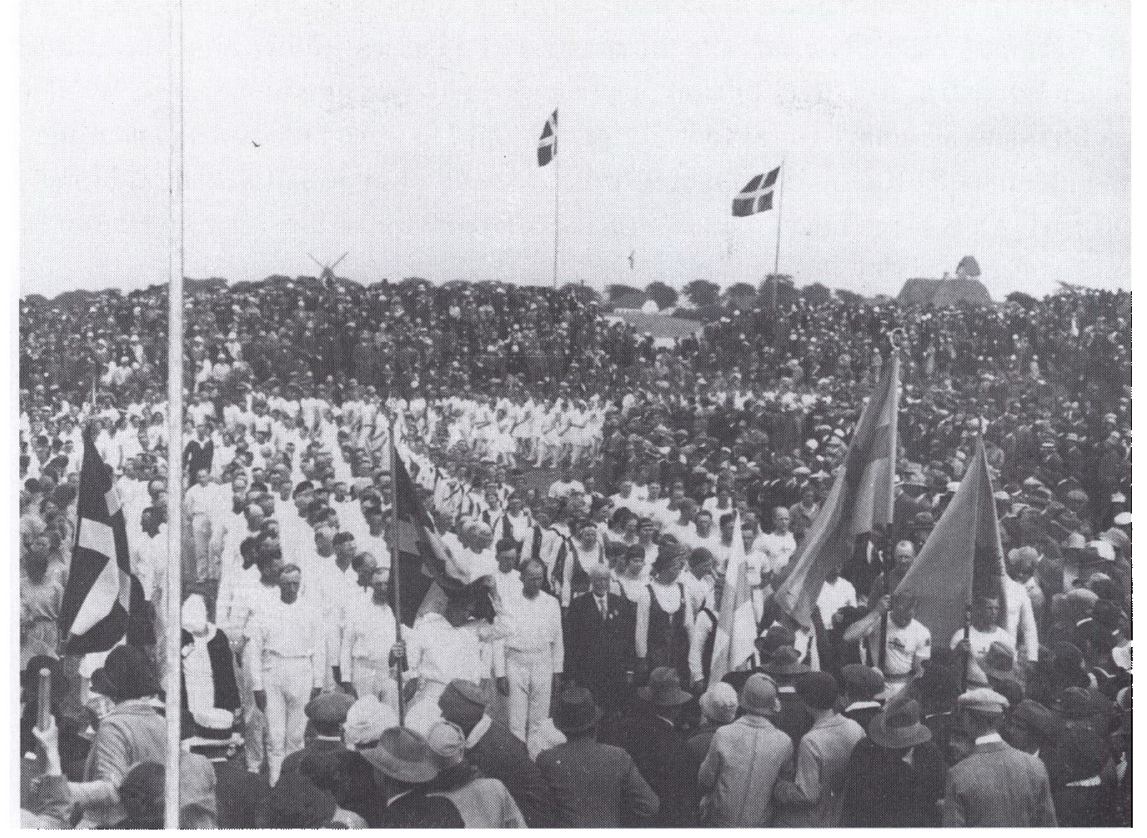

Gymnastikstavnet på Dybbøl juni 1933 havde en noget anden anden karakter end mindefesten tre år tidligere. Den var $i$ høj grad fremadrettet og var direkte affodt af den nazistiske magtovertagelse $i$ Tyskland og rumlerierne omkring 1920-gransen. Overordentlig mange af deltagerne medvirkede aktivt i gymnastikopvisningerne. Både tilskuere og talere var yngre end i 1930, og kun én taler var falles for de to fester. Det er ikke overraskende H.P. Hanssen. Arrangorerne af stavnet oprettede foreningen Det Unge Gransevarn $i$ somren 1933. Fotoet er optaget af en af dagens talere Ernst Christensen fra Asserballe. Museet på Sonderborg Slot.

særdeles nærliggende på Dybbøl, som først var ramme om den danske nations store nederlag, derpå stedet for fjendens sejrsfester - og til sidst ramme om Genforeningsfesten.

\section{Danske møder og fester på Dybbøl efter 1920}

Også efter Genforeningssommeren har Dybbøl dannet ramme om en række store dansknationale sammenkomster. Den mest fremadrettede og betydningsfulde var Ungdomsmødet på Dybbøl 11. juni 1933. Det var et stort gymnastikog sangstævne med 35.-50.000 deltagere, hvoraf de 20.000 gik i optog fra Sønderborg over broen op til banken. Stævnet var bevidst lagt én uge før et tysk ungdomsstævne i Rendsborg. Landmand Chr. Nielsen, Vollerup bød velkommen og udtrykte stævnets idé således: »Vi unge er stævnet sammen for 
på klar og bestemt måde at vise, at vi står på samme linje, i samme front, som vore fædre stod ${ }^{36}{ }^{36}$ Næsten alle talere, fra H.P.Hanssen til den unge lærerinde Inger Enemark, tog dette billede op. Den sønderjyske ungdom var her samlet på fortidens slagmark for at føre nutidens kamp. Samme billedsprog anvendtes af Valdemar Rørdam i den Dybbøl-sang, som han havde skrevet til ungdomsstævnet. Den blev sunget af den titusindtallige skare »i fast og roligt tempo" til Th. Aagaards melodi:

Dybbøl er bankernes banke i ringen, synskredsen rummer alt vundet og tabt. Æren og skammen her undslipper ingen, udvendig skæbne blev indvendig skabt.

Her står vi midt i vor helligdom, landet midt $i$ vor jordiske evigheds hus. Brødkornet her er med blodsveden blandet ånd har vi udgydt $\mathrm{i}$ vindenes brus..

Vort skal de vide, vi agter at værne, rodfast med rejsning mod tegn, som er ny. ${ }^{37}$

Ungdomsstævnet blev transmitteret $i$ radioen og refereret $i$ landspressen langt ud over, hvad der var sædvane for stævner af denne art. Den store pressedækning fra Dybbøl var med til at give Det unge Grænseværn, som stævnet lagde spiren til, en flyvende start - og understrege Dybbøls symbolværdi for alle.

Modstanden mod nazismen blev således manifesteret på Dybbøl allerede $\mathrm{i}$ somren 1933. Dennne åndelige opmarch på Dybbøl var med til at befæste det nationale sindelag hos mange, og dette blev af særlig betydning under de fem års besættelse.

I krigsårene var det ikke muligt at lave stævner på Dybbøl, men stedets danske symbolværdi blev ikke mindre af den grund. Og det var ikke et tilfælde, at den eneste proteststrejke, der forekom i Sønderborg under besættelsen, netop fandt sted en 18 . april. . $^{38}$

I sommeren 1945 kunne det danske folk fejre såvel befrielsen som 25 året for Genforeningen. Det skete ved en stor fest på Dybbøl den 11. juli, hvor kongehus, regering, folketing og en tusindtallig folkeskare deltog. I de fleste taler blev Dybbøls betydning som symbol på danskheden understreget.

Ved denne lejlighed viste det sig, at der i 1920 var grundlagt en tradition for Dybbøl-fester, som kunne videreføres og tåle genbrug. Denne tradition kan opfattes som typisk dansk med en blanding af samfundets top og almindelige 
borgere. Dybbøl-festerne prægedes af taler, musikindslag og fællessang. Traditionen kan følges ved fester 18. april 1964, 11. juli 1970 og 11. juli 1980. Under planlægning er en tilsvarende Dybbølfest i 75 året for Genforeningen i 1995.

Til mindefesten i 1964 skrev redaktør Carl Th. Jørgensen en Dybbøl-sang på melodien "Venner ser på Danmarks kort«. Den har siden da været populær og rummer, hvad der for mange er essensen af Dybbøl som dansk begreb efter 1920. I slutstrofen udtrykkes det således:

Hverdagens jævne arbejdssang, god at nemme - kær at nynne, stedse Dybbøl skal forkynde over krig og krisers gang. Byfolk - bønder sammen stævner, førtes frem af nye evner. Jorden bar og bølgen bar det blev Danmarks Dybbøl-svar. ${ }^{39}$

\section{Tysk brug af Dybbøl efter 1920}

Efter Genforeningen var det kun Knivsbjerg, som dannede ramme om tyske fester. Ganske vist stod Düppel-Denkmal fortsat med sit gotiske spir og vidnede om, at området havde været tysk, mens Bismarck-statuen var fjernet fra tårnet på Knivsbjerg. Alligevel synes Dybbøl efter Genforeningsfesten i 1920 at have så meget dansk udsagnskraft, at det tyske mindretal ikke benyttede det til fester. Det tyske mindretal markerede sig kun på Dybbøl den 18. april i forbindelse med kransenedlæggelser, der altid foregik på et andet tidspunkt end den tilsvarende danske højtidelighed. Denne skik har man fra begge sider fastholdt - og gør det endnu i 1992. Det militære samarbejde i NATO afspejler sig således ikke på Dybbøl.

I de få tyske publikationer om Dybbøl, som er udgivet i de senere år, lægges hovedvægten på at fortælle om de tyske krigergrave og den militære kamp i 1864. Derimod er der så godt som intet om Dybbøl som tysk symbol. Det hænger måske sammen med, at Düppel-Denkmal blev ødelagt af ukendte gerningsmænd 17. maj 1945. Der er i dag kun bevaret ét af fire relieffer på foden. Alt andet er forsvundet, og hele anlægget omkring mindesmærket er fjernet, så der er i dag intet på Dybbøl Banke, der erindrer om, at her har været et markant tysk mindesmærke.

I 110 året for stormen på Dybbøl bragte Flensburger Tageblatt en feuilleton om krigen i 1864, som også er udgivet $\mathrm{i}$ bog under titlen »Die Düppeler Chanchen ${ }^{40}{ }^{40}$ Forfatteren Wilhelm C. Hambach giver her $i$ litterær form sin 
tolkning af krigens lære. For hovedpersonen bliver Dybbøl skanser og kampen her en chance for at lære fredens pris. Samme meget lidt militante brug af Dybbøl som begreb fremgår også af en række stile, skrevet i 1992 af gymnasieelever i det tyske gymnasium i Aabenraa, og som vil blive omtalt nedenfor.

\section{"Dybbøl Mølle maler helt ad h.. til«}

Jo stærkere et nationalt symbol er, desto større er muligheden for at bruge og misbruge det til andre formål end det oprindelige. Generelt er der kun lavet meget lidt satire over de sønderjyske symboler og nationale mindesmærker. Det synes, som om den skæbnetyngede historie har hindret såvel ironi og satire som det billige grin $i$ at udfolde sig over temaet Dybbøl.

Ganske vist blev mange - ikke mindst folk i Dybbøl sogn - fortørnede i 1970, da årets landeplage inden for den folkelige musik blev sangen "Der er noget galt i Danmark« med omkvædet »Dybbøl Mølle maler helt ad Helvede tik«. Men fortørnelsen skyldtes nok især, at de fleste ikke havde lyttet til teksten, kun til omkvædet. Sangeren John Mogensen fik med denne tekst, som han selv havde skrevet, sit egentlige gennembrud. Han var en ener og fornyer af dansk populærmusik og skrev selv både sine melodier og tekster. Hans sange fremtræder $i$ en typisk dansk, jævn og folkelig form, men de rummer mere, end formen lader ane. Samfundskritik og livsfilosofi er indflettet i teksterne, som nok kan bide lidt. Omkvædet med Dybbøl Mølle lyder således:

Der er noget galt i Danmark

Dybbøl Mølle maler helt ad helved" til

Bare tegnedrengen er $\mathrm{i}$ orden

kan man få det som man vil.

Blæse vær' med andres mening

selvom det er dem der står for skud.

Det er noget skævt i toppen,

no'et der trænger til at skiftes ud. ${ }^{41}$

Mogensen havde skrevet omkvædet som en skjult hentydning til en af de smukkeste, danske fædrelandssange "Som en rejselysten flåde«, skrevet af Helge Rode til Genforeningen i 1920. Her skildres Dybbøl Mølle som symbol på hele danskheden i Sønderjylland:

Eget brød til egen dug,

Danmarks hvede, Danmarks rug

Dybbøl Mølle maler. ${ }^{42}$ 
Mogensens sang virkede stærkt ved sin fremkomst i sommeren 1970. Det var ret kort tid efter 50 års-festen for Genforeningen, og begrebet Dybbøl stod i fornyet skær hos mange. Hertil kom, at samfundskritiske sange af denne art endnu var en ret ny genre.

\section{Arkitektkonkurrencen i 1989 om besøgscenter på Dybbøl Banke}

Gennem 1980-erne har Miljøministeriets Fredningsstyrelse (i dag Planstyrelsen) arbejdet med fredninger på Dybbøl Banke, opkøb og nedrivning af skæmmende bygninger og tilrettelæggelse af nye stiforløb. I 1989 - 125året for 1864-krigen - blev skanse 4 ført tilbage til sin oprindelige omkreds, men skansevoldene blev ikke genetablerede. I flere år havde der været tanker om at lave et besøgscenter i tilknytning til Hotel Dybbøl Banke (Hotel Düppelhöh i tysk tid). Disse planer endte med nedrivning af det tyske bygningsværk og udskrivning af en offentlig arkitektkonkurrence om et større besøgscenter på byggegrunden. En stor donation fra Åge V. Jensens Fonde muliggjorde dette projekt. Byggeri og drift skulle forestås af Fonden Dybbøl banke. Til konkurrencen indkom 192 forslag, der alle blev udstillet på Museet på Sønderborg Slot december-januar 1989-90. En gennemgang af projekterne - med tilhørende begrundelser for hovedidé, udføring og materialevalg - viste, at Dybbøl i lighed med andre nationale symboler kan bruges til at begrunde helt modstridende holdninger. ${ }^{43}$ For nogle arkitekter, f.eks. Christian Oxenvad (projekt nr. 64) skulle besøgscentret ikke blot fortælle om krigen i 1864, men også om Danmarks forhold til Europa og EF. Det skulle »være Det Danske Hus i Danmark på kanten til Europa«. Nutiden skulle kobles på 1864, og Dybbøl-begrebet skulle fremme en positiv holdning til integration i EF.

Helt andre holdninger fandtes $i$ andre projekter, f.eks. Niels Jeppe Hansen, nr. 56, der lagde vægten på at skabe en scenografi omkring et stort monument over krigen. "Den besøgende kommer for at fornemme krigen i 1864 og opleve et ekko fra en tid, hvor forsvaret af Dybbøl blev et symbol på national tapperhed og mod. Det første, den besøgende møder, er centeret der er som et monument - et skulpturelt Guernica - udtrykker krigen, akkompagneret af landskabets historie«.

Hovedparten af projekterne lagde vægt på en vis grad af glorificering af de danske soldater. En 4. præmie tildeltes således Niels Sauer, der havde tilegnet sit projekt mindet om menig Hans Hansen, som faldt under voldsomme beskydninger af Dybbøl Bjerg i en alder af 21 år, dagen før den endelige storm på Dybbøl. Som begrundelse for valget af en menig citeredes militærhistorike- 
ren N. P. Jensen: «Det var den menige soldat og de lavere førere som hævdede vor militære ære og gav efterslægten den baggrund af folkelig bevidsthed, ud fra hvilken nationalitetskampen kunne føres. Mindet om Dybbøl blev tegn og løsen i denne kamp«.

Sammenfattende viste arkitektkonkurrencen, at der var stor interesse for at være med til at udforme et hus med et nationalt indhold - og at de mange, hovedsagligt yngre konkurrencedeltagere, tilsyneladende ikke var fremmede over for et stærkt følelsesbåret sprogbrug. Det nationale synes at indgå aktivt i sprogbrug og forestillingsverden hos den meget forskelligartede gruppe af arkitekter, hvoraf kun ganske få var bosiddende i Sønderjylland. Således kan man vurdere arkitekt-konkurrencen, hvis man er venlig. Hvis man vil være skarpere, så kan det nok forbavse, så let floskler og fraser falder i pennen hos folk, når de skal beskaftige sig med et hus på Dybbøl.

\section{"1864« Historiecenter Dybbøl Banke}

Resultatet af arkitektkonkurrencen blev valget af arkitekterne Michael Freddie og Ernst Lohses forslag. Dets hovedidé skildres af arkitekterne således: "Selve bygningen er udformet som et skarpt hjørne på en forsvarsbastion. Som et nationalt minde vælder den op af jorden, et minde om krigens gru - et

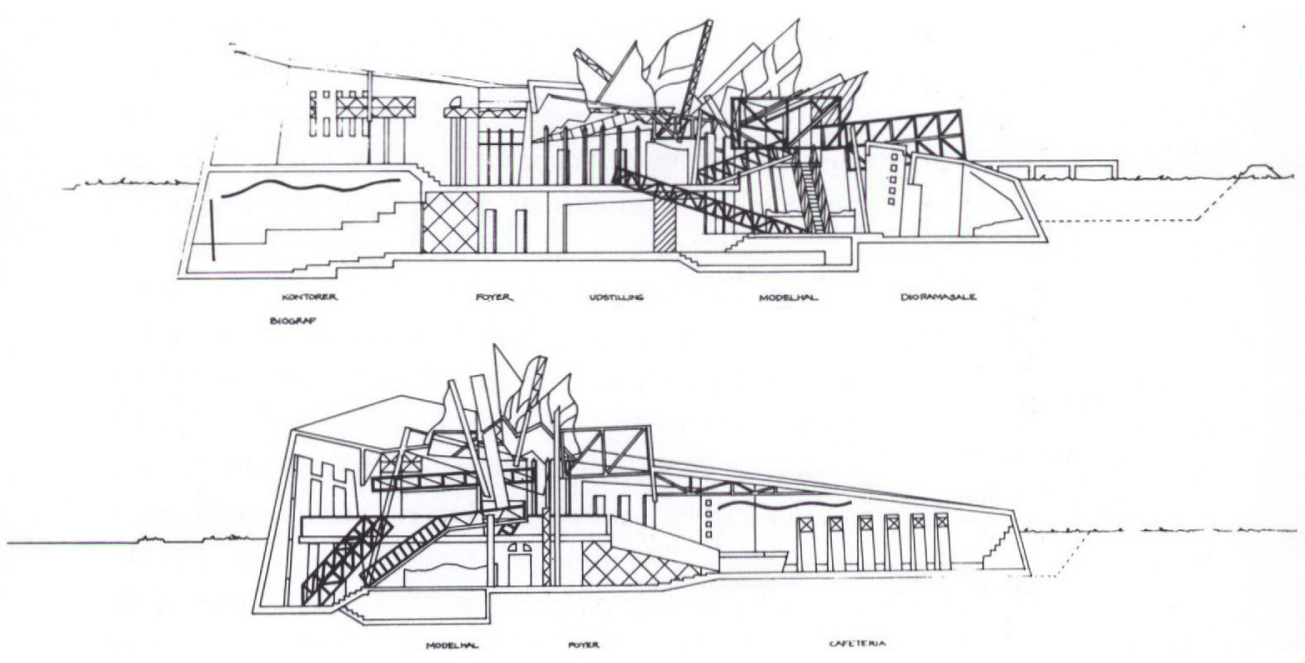

Historiecentret pd Dybbel Banke er tegnet af arkitekterne Michael Freddie og Ernst Lohse. Det er udtankt som et skarpt hjorne på en bastion, og - med arkitekternes egne ord - valder det op af jorden som et nationalt minde. Snit gennem bygningen fra det pramierede projekt. Foto Museet på Sonderborg Slot. 
ragnarok da Danmark blev løbet over ende - men samtidigt et vidnesbyrd om mod, styrke og vilje til at overleve. Bygningen skal opleves som en gennemskudt skanse, hvor de nationale symboler - Dannebrog - krigstrofæer - trods erobringen dog har formået at holde stand. Vi har brugt meget ekspressive former til at udtrykke den voldsomhed, der prægede begivenhederne ved Dybbøl. Besøgscentret skal være et monument i landskabet - et romantisk monument for danskheden - placeret netop i Dybbøl, som blev beviset på, at Danmark var værdig til at overleve som nation. ${ }^{44}$

Det er ingen tvivl om, at den symboltyngede arkitektur tiltalte dommerkomiteen. I begrundelsen for valget fremhæves at "projektet er kunstnerisk overbevisende og udtrykker på en klar og ekspressiv måde stedets drama og besøgscentrets formål ${ }^{45}$

Helt på linje med arkitekternes sprogbrug og begrundelse var formanden for Fonden Dybbøl Banke, amtsborgmester Kresten Philipsen, da han i 1990 tog det første spadestik. Ved denne lejlighed udtalte han, at Dybbøl var »det sted, hvor vi tabte Danmarkshistoriens flotteste nederlag « ${ }^{46}$

Historiecentret bygger $\mathrm{i}$ lighed med tidens øvrige besøgscentrer på forstillingen om, at de besøgendes største ønske er oplevelse og ikke trangen til erkendelse og fordybelse. Hvorvidt denne forestilling er rigtig, vil besøgstallet i de næste par år vise.

\section{Danske og tyske gymnasieelever om Dybbøl som symbol i 1992}

Dybbøl-området besøges fortsat flittigt, og det inddrages ofte $\mathrm{i}$ historieundervisningen både $\mathrm{i}$ folkeskolen og gymnasiet. Men én ting er lærernes brug af stedet $i$ historieundervisningen, noget helt andet er elevernes oplevelse af stedet og den symbolik, der er knyttet til det.

For at give en antydning af, hvad nutidens unge forbinder med Dybbøl, har to klasser fra henholdsvis Deutsches Gymnasium i Aabenraa og Sønderborg Gymnasium i perioden januar-marts 1992 skrevet stile om Dybbøl og den dansk-tyske historie. ${ }^{47}$ Den tyske klasse (1.b sproglig linje) omfattede 15 elever, hvoraf hovedparten, men ikke alle kom fra hjemmetyske familier. Der var imidlertid ingen egentlige forskelle i bedømmelsen - uanset hvilken national identitet eleven gav udtryk for. To karakteristiske konklusioner på stilene lyder således:

"Den tysk-danske historie har i dag - trods de historiske belastninger - ingen betydning for min hverdag som medlem af det tyske mindretal. Ungdommen $i$ almindelighed gør sig i dag ingen tanker om historien og Dybbøl. Det er dog 
alligevel rigtigt at befatte sig med historien for at formindske spændingen mellem dansk og tysk eller få dem til at forsvinde«. (Tina)

"Dybbøl og krigen i 1864 betyder intet for mig og mit liv. Det skyldes, tror jeg, at der er gået så lang tid siden da. Og måske skyldes det også at krige slet ikke er mit interessefelt. Men Dybbøl Skanser er ganske interessante og hører med til almen dannelse ligsom navnene på Christoffer Columbus’ tre skibe«. (Christian)

Da Dybbøl tilsyneladende ikke er med til at give unge tyskere eller tysksindede en styrket national identitet, kan det være rimeligt at overveje, hvor de unge så finder deres identitet. Dette spørgsmål har flere af de tyske elever inddraget, og svaret er for en af drengene klart. Hans identitet ligger i sproget eller rettere sprogene, idet han er tresproget: tysk, dansk og sønderjysk. Flersprogetheden er med til at give ham en sønderjysk identitet.

Også en dansk sproglig klasse, 2 a sproglig på Sønderborg Gymnasium, fulgte opfordringen til at skrive stile om emnet Dybbel. Denne klasse omfattede 25 elever, der i gennemsnit var godt ét år ældre end deres tyske kammerater. Stilene bærer i vist omfang præg heraf, og en direkte samføring er ikke mulig. En række typiske træk ved de 25 besvarelser springer imidlertid i øjnene allerede ved forste gennemlæsning. Hovedparten af eleverne har været meget forbavsede over at få stileemnet, og umiddelbart har en del af dem været afvisende eller tvivlende overfor, hvorvidt de overhovedet kunne skrive om emnet, der forekom dem fjernt. Men næsten alle har ikke desto mindre skrevet engageret $\mathrm{og}$ er $\mathrm{i}$ deres besvarelser gået langt videre, end opgaveformuleringen rakte. Emnet nationalsymbolik og Dybbøl har for de fleste af eleverne nær forbindelse med hele problemkomplekset national identitet og danskhed. Sidse udtrykker sig således: „Dybbøl og begivenhederne omkring Dybbøl, for ikke at glemme de forudgående begivenheder i Slesvig, har for mig altid stået som et symbol på dansk vilje til at stå mod og kæmpe for, hvad der var dansk, selvom overmagten var stor«.

Efter at have forsøgt at beskrive de associationer, som begrebet Dybbøl giver, er mange af eleverne gået videre og har funderet over forholdet mellem danskere og fremmede og Danmark i Unionen. Som én udtrykker det: "Dybbøl er noget, der får én til at tænke sig om. Men vi kan ikke leve på fortiden; vi må bruge Dybbøl, fortolke Dybbøl, så vi kan hitte ud af, hvordan vi skal være danske i dag“. Hovedparten af eleverne har en holdning som Chris, der udtrykker sig således: „Dybbøl Skanser bør være os en påmindelse om ikke at sætte de værdier over styr, som mange mennesker er gået i døden for at bevare."

Andre - især piger - giver udtryk for, at de nok ved, hvad der skete i 1864 , men der er noget helt andet, de associerer til på Dybbøl: »Jeg tænker aldrig på, at man tabte slaget til tyskerne her, for så ville jeg nok tænke på ubehag, 


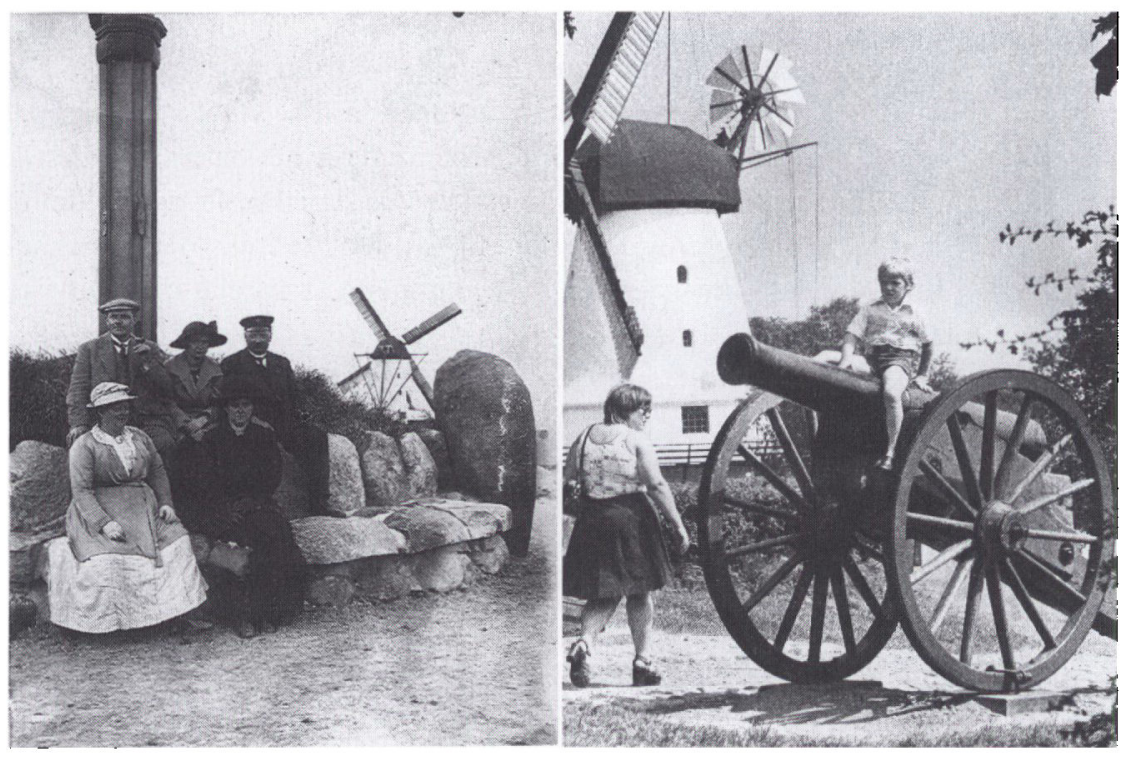

Lige fra Genforeningen i 1920 har Dybbol varet et sogt turistmål, hor man kom og dvalede ved nationens store minder. Til venstre er et selskab fotograferet ved den store flagmast $i$ begyndelsen af 1920erne. Jo fjernere en krig er, desto mere tillokkende synes den at vare som turistattraktion, og desto mere harmlost fremtrader dens militare udstyr. Til hojre ses kanonerne på Dybbal således anvendt som klatrestativer for småborn. De kan også bruges som dekorativ baggrund for optagelser af bry lhupsbilleder. Foto fra 1960erne. Museet på Sonderborg Slot.

når jeg gik $\mathrm{i}$ skanserne. Jeg forbinder det kun med det dejlige område deroppe, den dejlige natur. Jeg tror ikke det er fordi vi ved for lidt om krigen, men fordi vi ikke mere føler for det, der skete. Fordi det ikke længere er et spørgsmål om vores nationalitet, men en kendsgerning, vi er tilfredse med. Jeg tror, at det er mine nationalitetsfølelser, der først og fremmest gør det svært for mig at acceptere vores bevægelse ind i EF. Jeg ønsker at bevare min danskhed, vores sprog, vores mønt, vores flag.." (Mette)

Denne besvarelse er karakteristisk for hovedtendensen i de danske stile. De giver udtryk for en positiv vurdering af danskheden og dens indre værdier, og de rummer en positiv holdning over for den udfordring, som indvandrere og flygtninge stiller danskerne over for.

I udgangspunktet var holdningerne $\mathrm{i}$ de to gymnasieklasser ens. Det var forundring over emnet blandet med skepsis. Hurtigt synes denne holdning i begge klasser afløst af en villighed til at prøve at afklare sit eget forhold til det abstrakte tema. I den danske klasse viste det sig, at de fleste elever endte med at opdage, at de havde positive følelser overfor de nationale symboler. I 
den tyske gymnasieklasse var det markant, at absolut ingen gav udtryk for, at de følte stolthed over at komme til det sted, hvor en stor tysk sejr var foregået. Måske kan dette have sammenhæng med, at det var en klasse med elever fra Nordslesvig, elever der følte sig forbundne med både tysk og dansk kultur. I sammenligning med de tyske elever var de danske elevers holdning til Dybbøl langt mere positiv. Associationer til naturen, fædrelandet, danskheden og den forestående folkeafstemning om unionen var tydelig hos de fleste danske gymnasieelever.

\section{Hvad giver symboler livskraft?}

Vi har nu fulgt begrebet Dybbøl fra kampene i juni 1848 til indvielsen af historiecenteret $\mathrm{i}$ april og udgivelsen af den nyeste vandrefører over Dybbøl i maj 1992. Denne gennemgang har vist, at Dybbøl tilsyneladende fortsat er et livskraftigt begreb. Stedet og den historie, der har udspillet sig her, tillægges så stor betydning i Danmark, at det offentlige sammen med private fonde investerer over 50 mill. $\mathbf{k r}$ i synliggørelse heraf. Men hvad er hovedindholdet i de nutidige forestillinger om Dybbøl og krigen i 1864 ?

Når Dybbøl er blevet til et af de stærke danske nationale symboler, hænger det nært sammen med, at man har fokuseret på hærens indsats på Dybbøl forst og fremmest den 18. april - og valgt at se bort fra krigens årsager og optakt. Billedet af det lille land, der med ryggen op mod muren kæmpede heltemodigt mod en stor overmagt, var egnet til at troste og opbygge $i$ tiden efter 1864. Der er derimod intet opbyggeligt $i$ at fastholde erindringen om, at krigen kom som følge af rystende naivitet, manglende realitetssans og foruroligende inkompetance hos de ansvarlige danske politikere. ${ }^{48}$ Det var heller ikke fremmende for dansk selvbesindelse efter krigen at overveje hvor mange menneskeliv, der kunne være sparet, hvis regeringen ikke - hårdnakket og trods al fornuft - havde krævet Dybbølstillingen fastholdt. I det genopbygningsarbejde, der forestod efter 1864, lykkedes det at få vendt det store nederlag og den i militær henseende betydningsløse kamp til noget, det kunne give næring til en national genrejsning. Dybbøl er ikke et symbol på en glorværdig militærsejr, men et billede på en trofasthed ud over alle grænser. Denne forestilling er så fastgroet, at de fleste historiske værker om krigen fortier, at den danske hær var på bristepunktet, og der var tilløb til en omfattende lydighedsnægtelse blandt soldaterne, der skulle marchere til Dybbøl 15. april. ${ }^{49}$ Deserteringerne især af det slesvigske mandskab blev af overkommandoen anset for et så stort problem, at man udskilte ialt 1700 mand til at danne arbejdsbataljoner i Fredericia og på Als. 
Disse kendgerninger er nødvendig viden, hvis man skal tegne et sandt billede af krigen i 1864. Men symboler har ikke til opgave at give et dækkende billede. De indeholder kun den udvalgte del af historien, som en bestemt tidsperiode kan identificere sig med. Dybbøl er blevet et symbol på dansk udholdenhed og troskab i en sådan grad, at undervisningsminister Bertil Haarder i 1986 kunne fremhæve kampen på Dybbøl som et ufravigeligt tema i en historieundervisning båret af kvalitetskrav. ${ }^{50}$

I tysk perspektiv er Dybbøl et noget andet begreb. Her har dele af den ældre generation tilsyneladende endnu positiv interesse for Dybbøl som slagmark, men dets betydning som begyndelse til den tyske samling i 1871 indgår ikke som et væsentligt element $\mathrm{i}$ de publikationer, der laves om stedet. De sigter som allerede næunt mest på at give mulighed for at finde de tyske grave og mindesmærker i Dybbøl-området. I den unge generation synes interessen for den symbolik, der tidligere blev tillagt stedet, næsten at være forsvundet.

\section{Krigen som turistattraktion}

Det er rimeligt at antage, at Dybbøl i hvert fald i et par årtier endnu vil fastholde sin betydning som dansk symbol. Historiecentret på Dybbøl Banke vil utvivlsomt være med til at fastholde dette. Men der kan være grund - når centeret har fundet sin form - til at vurdere indholdet af den historieformidling, der her vil finde sted i betydeligt omfang. Formålet er dels at skabe en turistattraktion, dels - med centerlederen Hans Ole Hansens ord - at være med til at bære vort lands historier og historie ind $\mathrm{i}$ det 21 . århundrede og tydeliggøre den danske identitet. ${ }^{51}$ Især det sidste udtryk har fænget i dagspressens omtale af stedet. JydskeVestkysten har således bragt en helsides omtale 28. januar 1992 under overskriften "Identiteten ligger i Dybbøl«. I en leder 19. april 1992 fastslås Dybbøls betydning for en nation på vej ind i et større fælleskab: "Selvfølgelig skal vi huske, hvad der skete på Dybbøl. Og måske netop fordi vi led et smerteligt nederlag. Vi nutidens danskere har behov for at blive mindet om fortidens kampe. For at huske vore rødder. Men hvad der også er vigtigt for det nye historiecenter: Det skal være med til at minde os om vor identitet i fremtiden. Den får vi brug for. Dybbøl er ikke længere et nederlagets sted. Det er en historisk plads. En plads, der skal være med til at forankre danskheden på vej ind i det internationale stor-fællesskab. ${ }^{52}$

Det er med en vis skepsis, at man læser fortolkninger af denne art. Den danske identitet skulle helst hente sin næring fra kraftigere kilder end historien om nederlaget i 1864. Trods alle beskrivelser af en heltemodig indsats af den 
Den idealiserede fremstilling af kampene på Dybbol har varet fremherskende $i$ de 125 år, kamppladsen har varet et nationalt symbol. Prototypen på danske fremstillinger af de heltemodige soldater, der kamper trods den store overmagt, er et maleri af Vilhelm Rosenstand: 8. Brigades modstod. Dette billede indgår i mange forskellige udsnit $i$ historiecenterets film om stormdagen, og et udsnit anvendes på centerets informationsmateriale og plakater. Dets heroiske stil svarer til centrets budskab.

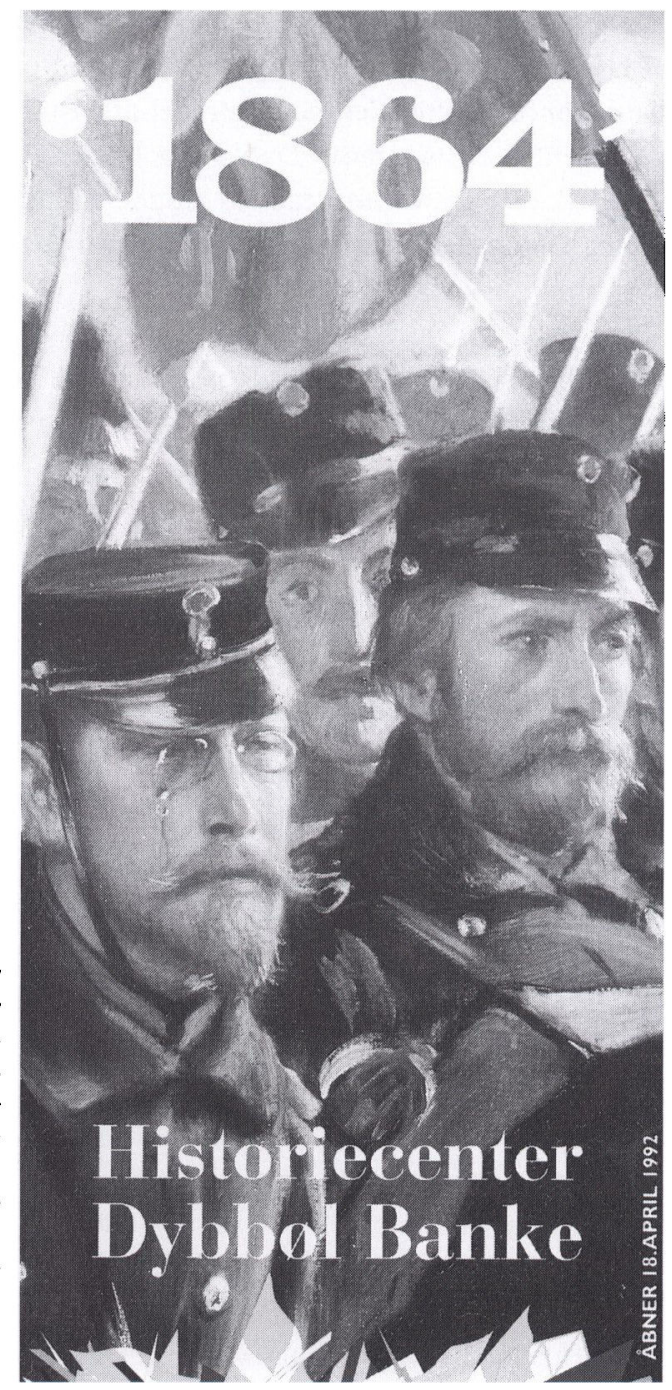

danske hær, herunder i høj grad de menige soldater, kan man ikke se bort fra de talrige fatale fejltagelser, som også foregik både før og under krigen. Digteren Chr. Richardt skrev i sommeren 1864 om den håbløshed, som var karakteristisk for krigsåret - og som ligger fjernt fra den hurra-patriotisme, som en eftertid undertiden har sløret kendsgerningerne med:

$\mathrm{Nu}$ blegner fast vort sidste håb, kun lavt vor stjerne står, 
og Danmark sidder som en Job

og skraber sine sår;

og vennerne de flokke sig,

de see os byld ved byld,

og trøste os så drøvelig:

"det er din egen skyld! $^{53}$

Den danske identitet, som efter lederskribentens mening bør forankres på grund af den forventede indtrædelse i EF-unionen, ligger den egentlig på Dybbøl i 1864? Således er det fremført gentagne gange i løbet af det sidste års tid i forbindelse med opførelsen af historiecentret. Det kunne være rimeligt at spørge, om vi ikke snarere burde søge forankring for identiteten i tidsperioden 1865-1914? I disse 50 år lykkedes det for de danske sønderjyder at fastholde deres sindelag trods et massivt fortyskningsforsøg. For det stærkt reducerede Danmark, som mange troede ikke ville overleve som selvstændig nation, lykkedes det trods indre politisk splid at klare omstillingen fra at være en af de mellemstore, ganske betydende europæiske magter til at være en næsten betydningsløs lilleputstat, der kun kan overleve på indre værdier. Også denne del af historien er blevet besunget $i$ en fædrelandssang "Jeg ser de bøgelyse øer«. Det er en på én gang smuk og virkelighedsnær sang, der forsager at beskrive det danske folk og den historie, der binder individer sammen til et folk:

Jeg ser de slægter, som gik hen, mens hundreåret skred, som vandt på Kongedybet, som under Dybbøl led;

de elsked ungt, de drømte langt, de så kun alt for kort, men frem af dem stod folket. Og dette folk er vort. ${ }^{54}$

Beretningen om den nyorientering, som fandt sted efter 1864, og skildringen af den nationale mobilisering i Nordslesvig, efter området var blevet tysk, er mere forankrende og inspirerende for dansk identitet $\mathrm{i} 1992$ end den gamle vin (dvs. krigen) på nye flasker. Historien, der udspiller sig efter 1864, rummer blot ét problem: Den er ikke velegnet til en dramatiseret iscenesættelse som turistattraktion. Det er derimod krigen, hvis man - som i historiecentret på Dybbøl - fokuserer på de heltemodige episoder, som f.eks. 8. brigades modstød, og ser bort fra alle de fatale fejltagelser.

Idealiseret krigshistorie er altid nærende for den nationale stolthed. Derfor vil der fortsat være interesse for krigen på Dybbøl i 1864. Men en god historieformidling bør altid trække perspektiver både tilbage og frem i tiden. Den mest spændende historie udspiller sig, efter Dybbøl er ophørt at være 
slagmark. Den historie vil kunne fænge unge i en tid, hvor nynationalismen blomstrer frem, samtidigt med at nationalstaterne er under omdannelse.

\section{Sejre til nederlag}

Gennemgangen af Dybbøl som dansk og tysk symbol har vist, at symboler ikke har en absolut værdi, men kun genspejler, hvad en bestemt tid lægger i dem. Men den viser tillige det paradoks, at symbolet for sejrherrene helt har mistet sin kraft, mens det for den tabende part har fået en overordentlig stærk betydning, så stærk at den manifesterer sig i oprettelse af et historiecenter midt på det sted, hvor nederlaget udspillede sig. Imidlertid er der ikke tale om et paradoks, men om bekræftelse af en iagttagelse, som den franske litteraturforsker Roland Barthes har gjort: „Hvis jeg var Gud, ville jeg vende alle sejre til nederlag - hvad Gud for resten også gør«.

En vandretur i Dybbøl Skanser og en lystrejse i Højskolesangbogen viser, at det omvendte også kan finde sted: Erkendelse af svaghed kan blive til en klar styrke. Derfor er det vigtigt, at opmærksomheden altid - også når talen er om begrebet Dybbøl - rettes mod hele historien på godt og ondt og ikke kun den tilsyneladende glorværdige del.

\section{NOTER OG HENVISNINGER}

En varm tak til 1 a og adjunkt Frauke Jessen på Deutsches Gymnasium i Aabenraa samt 2 a og adjunkt Jørgen Olaf Nielsen på Sønderborg Gymnasium for aktiv medvirken.

I. Gerd Stolz: Düppel - Düppel 1848 - 1849 - 1864 - heute. Ein historischer Wanderführer über die Düppeler Höhen. Sønderborg 1992 s. 4.

2. Frits Holst \& Axel Larsen: Felttogene i vore første Frihedsaar. 1988, s. 220.

3. Sammestds.

4. Dybbøl Sogns Historie, 1976, s. 363.

5. Johs. Nielsen: 1864 - Da Europa gik af lave. 1987, s. 68 .

6. Dybbøl Sogns Historie, 1976, s. 368.

7. Breve fra Krigsaaret 1864. (Stænderdeputeret Jørgen Hansen i Ravnskobbel, Dybbøl sogn) Udgivet Af H. P. Hanssen i 1914 som særtryk fra Hejmdal.

8. I de militære værker er der ret forskellige opgivelser af tabene den 18. april. I Den dansk-tyske Krig 1864, udgivet $i$ af den danske generalstab i 1891, opgives de danske tab til følgende: 379 faldne, 920 sårede, 649 savnede, hvoraf mange sikkert er faldne, og 2879 usårede fanger. De tyske tab var 263 faldne, 909 sårede og 29 savnede. I den nyeste behandling af krigen Johs. Nielsen, 1987 gengives s. 261 de samme tal. Den grundigste undersøgelse af emnet er fremlagt i V.Cohen: Krigen $1864 \mathrm{og}$ de faldnes minde. Her er antallet af savnede skåret kraftigt ned, da over 500 kan opføres som døde jvf. oplysninger Cohen har indhentet. N.P. Jensen: Den anden slesvigske krig 1964, udgivet 1900, gengiver Cohens tal. Derimod er der helt andre tabstal angivet - uden nærmere forklaringer $-i$ den mest omfattende behandling af krigen til dato: Svend Bjørke $\mathrm{m}$. fl: Krigen 1864, udgivet i 1968. Her opgives disse tal: 77 døde, 554 sårede, 3543 fanger og 
660 savnede. Det er ganske uforståeligt, hvorledes forfatterne er kommet til dette lave antal døde. På terrænet i skanserækken og ned mod Alssund er jordet alene 421 danske krigere, hertil kommer gravene på Dybbøl kirkegård samt Sønderborg og Augustenborg kirkegårde. se også J.Slettebo: Hvad døde de an? (I: Skalk, 3, 1992).

9. Theodor Fontane: Der Schleswig-Holsteinische Krieg im Jahre 1864, Berlin 1866, s. 191-92.

10. Johs. Nielsen 1987, s. 261.

11. P. Holst: Dybbelskandserne. 1864, s. 29.

12. Her gengivet efter $I$. Adriansen: 1864 i samtidens aviser, 1976, s. 45.

13. Dagbladet 20.04.1864. Her gengivet efter Adriansen 1976 s.48.

14. Fontane 1866, s. 204.

15. Der Tag von Düppel af Fontane er bl. a. gengivet i Vaterländisches Lesebuch, Halle 1888, s. 308.

16. Der Deutsch-Dänische Krieg 1864. Udg. af Grossem Generalstabe Berlin 1887, s. 528.

17. Wollmann: Geschichte des Brandenburgischen Pionier-Bataillons Nr. 3., Minden 1888, s. 83.

18. Geibels digt er bl. a. gengivet i Schleswig-Holsteinischer Kinderfreund von Georg Wagner, Leipzig 1903 s. 340.

19. P.F.L. Hoffmann: Der Schleswig-Holsteinische Befreiungskrieg im Jahre 1864, Flensborg 1914, s. 200. Den nyeste behandling af Klinke-myten er Werner Bader: Pionier Klinke. Tat und Legende. Berlin 1992.

20. Fontane 1866, s. 203.

21. Otto Vaupell: Johan Ancker og Skanse Nr. II's Forsvar (I: Danebrog, 1988, s. 634).

22. Otto Vaupell 1882 s $593 \mathrm{ff}$.).

23. Museet på Senderborg Slot har i 1864-arkivet en samling telegrammer og hilsener, som er blevet fremsendt til enkefru Ancker hvert år den 18. april.

24. H.V. Clausen: Sønderjylland, 1932, s. 123.

25. Erik Skram: Hinsides Grænsen, 1888, s 52.

26. Ole Andersen: Festung Sonderburg Düppel. To spionrapporter. (I:Sdj. Månedsskrift, 1991, s. 10-17) samt utrykt manuskript af samme: Festung Sonderburg-Düppel 1865-1885.

27. Holger Drachmann: Derovre fra Grænsen, s.64. Her efter Genforeningsudgaven 1919.

28. Drachmann, 1919, s. 65-66.

29. Sonderburger Zeitung 6.09.1890.

30. Sonderburger Zeitung 29.061914.

31. Sammestd.

32. Robert Ludvigsen: En konges Ridt, 1920.

33. Ludvigsen 1920, s. 58.

34. Sammesteds s. 59.

35. Ludvigsen 1920, s. 67.

36. Knud Fanø, Fr. Rudbeck og Inger Bjørn Svensson: Det unge Grænseværn DUG, 1983, s. 44.

37. Fane, 1983 s. 49.

38. Age Trommer: Modstandsarbejde i Narbillede, 1973, s. $234 f$.

39. Sanghæfte fra 1964-festen i arkivet vdr. Dybbøl på Museet på Sønderborg Slot.

40. Wilhelm C. Hambach: Die Düppeler Chancen, Flensborg 1974.

41. John Mogensens Sangbog, red. af John Rasmussen, 1992, s. 22-23.

42. Fra festspillet "Moderen« af Helge Rode. Det opførtes på Det Kgl. Teater i Genforeningsåret. Sangen indgår i Højskolesangbogen.

43. De følgende gennemgang af udvalgte projekter bygger på mine notater fra udstillingen. Alle projekter blev tilbagesendt i februar 1990.

44. Citat fra projektbeskrivelsen. Findes i afskrift i arkivalier vrd. Historiecentret på Dybbøl Banke på Museet på Sønderborg Slot.

45. Konkurrencen om Besøgscenter på Dybbøl Banke. Dommerbetænkning, s. 6. Museet på Sønderborg Slot.

46. JydskeVestkysten 3. april 1991, 2. sek, Sønderborg-udgaven.

47. Alle stile vdr Dybbøl som nationalt symbol findes i arkivet på Museet på Sønderborg Slot. 
48. K.V. Nielsen i Militært Tidsskrift, 1987, s. 194.

49. Johs. Nielsen, 1987, s. 247-48. Her redegøres for episoden med lydighedsnægtelse 15. april.

50. Se debat herom mellem Bertel Haarder og Karl Brøcher i tidsskriftet Folkeskolen 1986, s.17741775 og 1959.

51. Hans Ole Hansen: Historiecenter Dybbøl Banke - Et historiens fortællehus. I: Sdj. Månedsskrift, 1992, s. 148.

52. JydskeVestkysten 18. april 1992, 1. sektion s. 8.

53. Chr. Richardt: Samlede Digte, bd. 1, 1895.

54. L.C.Nielsen: Jeg ser de bøgelyse øer (I: Vårdigte 1901). Her efter Folkehøjskolens Sangbog 17. udgave, 1989, nr. 174. 